\title{
A REVISION OF THE DRAGONETS REFERABLE TO THE GENUS CALLIONYMUS FOUND IN THE WATERS OF JAPAN
}

\section{$\operatorname{AUTHOR(S):~}$}

Ochiai, Akira; Ochiai, Akira; Araga, Chuichi; Nakajima, Matuso; Nakajima, Matuso

\section{CITATION:}

Ochiai, Akira ...[et al]. A REVISION OF THE DRAGONETS REFERABLE TO THE GENUS

CALLIONYMUS FOUND IN THE WATERS OF JAPAN. PUBLICATIONS OF THE SETO MARINE BIOLOGICAL LABORATORY 1955, 5(1): 95-132

\section{ISSUE DATE:}

1955-12-20

URL:

http://hdl.handle.net/2433/174531

RIGHT: 


\title{
A REVISION OF THE DRAgONETS REFERABLE TO THE GENUS CALLIONYMUS FOUND IN THE WATERS OF JAPAN
}

\author{
Akira OCHIAI, ChûIchi ARAGA and Matsuo NAKAJIMA \\ Department of Fisheries, Faculty of Agriculture, Kyôto University; Maizuru
}

With 12 Tables and 19 Text-figures

The fishes of the genus Callionymus, in which the genus Calliurichthys is synonymized in the present paper, are generally found on sandy or muddy shores in most of the tropical and temperate regions of the world, most plentifully in the Indo-Pacific region. They are very common in our waters and caught rather abundantly together with other shore fishes mainly for the domestic consumption and local sale.

The first actual revision of the Japanese fishes of this group was made in 1902 by JORDAN and Fowler, who placed eleven species in two genera, Callionymus and Calliurichthys. The genus Calliurichthys was erected by them for the accomodation of Callionymus japonicus, C. variegatus and their new species, C. doryssus, and it is distinguished from the genus Callionymus in having a preopercular spine simple, sharp, spear-like and a serrated edge, instead of being recurved at the tip, and armed with one or more recurved hooks above. Some remarks on this group have since been added by Jordan and HubBs (1925:317), Boeseman (1947:130-134) and others. In all, about twenty species of this group have been described from our waters. It appears, however, that the taxonomical studies of them that have hitherto been made are far from being satisfactorily understood since they vary externally so much according to sex, growth stage and even individuality, although they have long been of interest to some ichthyologists. In addition to this fact the present authors failed to find the significant morphological differences between these two genera, Callionymus and Calliurichthys, and accordingly prefer the older name.

The subject of this study is to determine the valid species of this group and to evaluate the extent of modification in the form and color pattern of the body due to sex and growth.

By examining a great deal of the Japanese specimens of this genus, the present authors recognized sixteen species as valid in Japan, including one which is described as new to science, and two which are reported as new to the fauna of our waters. Unfortunately no specimens of C. variegatus, C. calliste, C. valenciennesi and C. kita-

Publ. Seto Mar. Biol. Lab., V (1), $1955 . \quad$ (Article 7) 
harai have come under our examination. The original description of these species are abridged in this paper.

In the present work, the head length is indicated by a measurement from the tip of the lower jaw to the anterior margin of the gill-opening; the body width and depth are measured at the base of the first dorsal soft ray; the pectoral fin length is the distance from the middle part of the base to the tip of the fin; the pelvic fin length is recorded as a distance between the base of the pelvic fin and the tip of the fin. The coloration of the body and fins is described by the specimens deposited in formalin.

The writers of this paper wish to express their sincere gratitude to Prof. Kiyomatsu MATSUBARA, for his kind supervision during the course of this study. We also thank to Tatsuji UENo (Faculty of Fisheries, Hokkaido University), Masahiko TAKedA (Faculty of Agriculture, Kôchi University), Toshiharu Konada, Tamotsu IwaI and Hirotoshi Asano (Department of Fisheries, Faculty of Agriculture, Kyôto University), who sent us a number of valuable specimens of this group. The expense for executing the work of present study is defrayed from the research fund offered by the Ministry of Education from 1953 to 1954.

\section{Key to the Japanese species of Callionymus}

1 a . Opercular spine sharp, straight, saber-like, the upper margin finely serrated.

2a. 2 bony striated patches on top of occipital region, separated with each other; dorsal and anal soft rays 9 and 8 respectively; 1st dorsal ocellated with a large jet black blotch between 3rd and 4th spines; in male, anterior 2 dorsal spines elongated and filamentous, and chest with a black blotch.

.C. japonicus HOUTTUYN

Syn. C. numeri TANAKA

$2 \mathrm{~b}$. A broad rugosely striated bony patch on top of occipital region; dorsal and anal soft rays 8 and 7 respectively; 1st dorsal not ocellated with black; in male, anterior 2 dorsal spines elongated and filamentous; a blackish blotch on the chest and 1 or 2 black ocelli on the flanks .................................... variegatus TEMmINCK et SCHLEgEL

2c. Upper surface of head entirely smooth; both dorsal and anal with 9 soft rays; 1st dorsal not ocellated with black; dorsal spines all produced into filaments except for young; in male, under side of head uniformly pale ...C. doryssus (JORDAN et FOWLER)

1b. Preopercular spine recurved at the tip, the upper margin armed with 3 or more recurved hooks.

3a. Dorsal soft rays 8; anal soft rays 7 ; lateral line not connected by a branch with a fellows of opposite side on upper surface of caudal peduncle.

4a . Eye smaller, about $1 / 4$ as long as head; in male, dorsal spines long and filamentous, anal greyish white except for blackish margin; in female, dorsal spines not filamentous, anal uniformly yellowish.................... calliste JORDAN et FowLER

$4 \mathrm{~b}$. Eye larger, about $1 / 3$ as long as head; in male, dorsal spines all prolonged into Filaments, the fin membrane black with some whitish zig-zag lines; in female, dorsal spines all completely connected by membrane, the fin membranes black except for anterior part C. phasis GüNTHER 
$3 \mathrm{~b}$. Dorsal and anal each usually with 9 soft rays; lateral line connected by a branch with a fellow of opposite side on upper surface of caudal peduncle.

5a. Preopercular spine rather thick, with 5 or 6 sharp hooks on the upper margin; head flattish, wider than long; in male, 1st dorsal pale, vermiculated with black; in female, the fin uniformly black................................ planus sp. nov.

$5 \mathrm{~b}$. Preopercular spine rather slender, with 3 or 4 sharp hooks on the upper margin; head moderately depressed, as wide as or narrower than long.

6a. Hindmost hook on preopercular spine barbed (Fig. 6) ; 2 median caudal rays more or less produced into filaments.

7 a. Dorsal soft rays all produced, much longer than head; in male, 1st dorsal grey, with 3 dark bands running obliquely, and dotted with an irregular black spot between 3rd and 4 th spines....................... sokonumeri KAMOHARA

$7 \mathrm{~b}$. Dorsal soft rays moderately long, as long as head; 1st dorsal with a blackish blotch between 3 rd and 4 th spines; in male, 2 median caudal rays especially elongated C. kaianus GüNTHER

$6 \mathrm{~b}$. Hindmost hook on preopercular spine not barbed; caudal rays either short or more than 2 rays produced.

8 a . Urinogenital papilla elongated (male).

9 a. Several median caudal rays elongated into filaments; dorsal spines greatly produced into long filaments except for 2 nd spine

C. flagris JORDAN et FowLER

$9 \mathrm{~b}$. Caudal fin not produced into filaments.

10 a. Dorsal spines not produced into filaments; sides of body crossed by numerous narrow oblique lines of light brown; outer margin of 1 st dorsal with a narrow black blotch of crescentic shape

C. punctatus LANGSDORFF

Syn. C. richardsoni BLEEKER

$10 \mathrm{~b}$. All or some of the dorsal spines produced into filaments, sides of body not crossed by narrow oblique lines.

11a. 1st dorsal spine elongated into long filaments, but other spines not especially elongated; a blackish ocellus behind the last dorsal spine C. lunatus Temminck et SCHLEGEL

$11 \mathrm{~b}$. Dorsal spines more or less produced into filaments.

12a. 1st dorsal spine the longest, the fin plain; anal edged with black C. huguenii BLEEKER

$12 \mathrm{~b}$. Anterior 2 dorsal spines longer than others; eye as large as or less than snout.

13a. 3 median rays of caudal longer than others; last dorsal and anal rays extending beyond base of caudal; 1st dorsal without large black spots; anal pale or black with numerous oblique wavy white lines.

C. beniteguri JORDAN et SNYDER

Syn. C. ornatipinnis REGAN;

C. kanekonis TANAKA

$13 \mathrm{~b}$. Caudal rounded, last dorsal and anal rays not extending beyond base of caudal; 1st dorsal with a few blackish spots; anal pale, but the outer edge black

.C. valenciennesi TEMMrNCK et SCHLEgeL

12c. Dorsal spines highly produced, the membrane high and joined to 1st dorsal soft ray at base; eye shorter than snout

C. virgis JORDAN et FOWLER 
8 b. Urinogenital papilla very short and rudimentary (female).

14 a. Last dorsal and anal soft rays not reaching base of caudal when the fins are depressed.

$15 \mathrm{a}$. Dorsal spines more or less filamentous, the 1 st spine the longest, reaching base of 2nd dorsal soft ray when the fin laid back; anal generally pale

C. flagris JORDAN et FOWLER

$15 \mathrm{~b}$. Dorsal spines not filamentous except for the 1st one, which scarcely or not reaching base of 1 st dorsal soft ray.

16a. 1st dorsal uniformly black.

17 a . Eye moderately large, about as long as snout; sides of anal black medially...C. lunatus TEMMTNCK et SCHLEgel

$17 \mathrm{~b}$. Eye longer than snout; sides of anal not black medially......................... virgis JORdAN et FowLER

$16 \mathrm{~b}$. A dark blotch, crescentic in shape, present on spinous dorsal between 2nd and 3rd spines, and a similar but larger one between 3rd and 4th spines

C. kitaharai Jordan et Seale

$14 \mathrm{~b}$. Last dorsal and anal soft rays extending base of caudal when the fins laid back; anal pale.

$18 \mathrm{a}$. 1st dorsal with numerous dusky lines and whitish specks on membranes of anteriormost 2 spines, but the rest of the fin blackish

C. beniteguri JORDAN et SNYDER

$18 \mathrm{~b}$. 1st dorsal pale, with a large blackish ocellus between 3rd and 4 th spines C. punctatus LANGSDORFF

\section{Callionymus japonicus HoutTuYN}

Yome-gochi

(Fig. 1)

Callionymus japonicus.-HouTTUYN, $1782: 311$.

Callionymus longicaudatus.-TEMmINCK et SCHLEGEL, $1845: 151$, pl. 79, fig. 1; GÜNTher, 1861 : 148-149; NYström, 1887:36; DAy, 1889:303-304; BLEGVAd, 1944:174; BoESEMAN, 1947: 130.

Callionymus reevesii.-RTChardson, 1846:210; EvermanN et SEAle, 1907:103; RoXas et MARTIN, $1937: 241$.

Calliurichthys japonicus.-JORDAN et FowLER, 1903:942-943, fig. 2; SMITh et POPE, $1906: 493$; FrANZ, $1910: 84$; SN YDER, $1912: 446$; JoRDAN, TANAKA et SN YDER, $1913: 373$, fig. 330 ; JoRDAN et ThOMPSON 1914:294, fig. 71; IzUKA et MATsuura, 1920:190; Jordan et HubBs, 1925 : 316; MorI, 1928:8 ; Ur, $1929: 262$; Kuroda, $1931: 124$; SCHIMId, 1931b:141; Wu, 1931:56 ; Mori et Uchida, $1934: 21$; Nakamura, $1934: 25$; Kamohara, 1936:7; Kolke, 1936:13; Mako, 1949 ; 134; Katayama, $1950: 10$; YanaI, 1950:22 ; Chen, 1951:161; Kuroda, 1951 : 385 ; KaMOHARA, $1952: 89:$ MORI, $1952: 133$.

Callionymus numeri.--TANAKA, $1917: 12$.

Callionymus, Calliurichthys japonicus.-McCulLoCH, 1926:196-197.

Material examined.-Male. Nos. (Matsubara's Fish Coll.) 1178 and 1235, 145-211 mm in standard length $(255-354.5 \mathrm{~mm}$ in total length), locality unknown. No. $8862,140 \mathrm{~mm}$ (299 mm), Kanaiwa, Is hikawa Pref., October 26, 1942. No. 11106, $147 \mathrm{~mm}$ (251 mm), Kanaiwa, 
April 3, 1949. No. 11457, $204.5 \mathrm{~mm}$ (359 mm), Japan Sea, October 3, 1948. Nos. 15039, 15043 and 15047, 36-104 mm (50-173 mm), Saheki Bay, Ôita Pref., January 3, 1951. No. 21272, $117 \mathrm{~mm}$ (194 mm), Owase, Mie Pref., November 5, 1953. Nos. 21349, 21350 and 21352, 215-228 mm (376$425 \mathrm{~mm}$ ), locality unknown. Nos. 22006, 22011, 22014, 22017, 22019, 22023, 22025, 22032-22033, 22035 and 22037-22040, 70-207 mm (103.5-355.5 mm), Mimase, Kôchi City, April 10-20, 1954. Nos. 23252-23256, 99-277 mm (159-420 mm), off Shibushi, Kagoshima Pref., September 1-3, 1954. Nos. 23614-23617, 189-205 mm (360-396 mm), Yahatahama, Ehime Pref., October 10, 1954.

Female. No. $1489,167.5 \mathrm{~mm}(262 \mathrm{~mm})$, Owase, December 6-9, 1935. No. $11456,155 \mathrm{~mm}$ $(264 \mathrm{~mm})$, Japan Sea, October 3, 1948. No. 13046, $142.5 \mathrm{~mm}$ (223 mm), Wakasa Bay, May 1950. Nos. 15038, 15040, 15044-15045 and 15048-15050, 48-79 mm (71-123 mm), Saheki Bay, January 3, 1951. Nos. 15293-15294, 72-87 mm (106-130 mm), Owase, January 15-20, 1950 . Nos. 18557$18559,123-155 \mathrm{~mm}$ (204-257 mm), Mimase, October 10, 1952. Nos. 22007-22010, 22015-22016, 22018, 22020-22022, 22024, 22026-22031, 22036, 22038 and 22041-22043, 61-166 mm (86-258 mm), Mimase, April 10-24, 1954. No. 23068, $156 \mathrm{~mm}(246 \mathrm{~mm})$, Yahatahama, August 30, 1954. Nos. 24776-24777, 50.5-72 mm (73-112 mm), Owase, October 25, 1954.

Description.-D. $1 \mathrm{~V}, 9$ to $10(9.0)^{*}$; A. 8 to 9 (8.0); P. 18 to 21 (19.5). Body width 5.7 to 9.2 (7.1) in standard length; body depth 8.8 to 15.5 (11.0); depth of caudal peduncle 16.7 to 25.5 (19.8). Eye diameter 2.5 to 4.5 (3.0) in head length; 3rd dorsal spine 1.2 to 2.2 (1.4); 4 th dorsal spine 1.4 to 3.0 (2.0); 1st dorsal soft ray 1.1 to 1.8 (1.3) 6th dorsal soft ray 1.1 to 1.7 (1.3); last dorsal soft ray 0.9 to 1.8 (1.2); pectoral fin 1.0 to 1.4 (1.2); pelvic fin 0.7 to $1.1(0.9)$.

Preopercular spine strong, sharp and straight, as long as eye, the upper edge finely serrated, and the basal spinule directed forward. Upper surface of occipital region with a pair of elevated crests, striated, and separated from each other by the smooth integument of head. Last dorsal and anal soft rays reaching base of caudal fin except for the mature male.

First dorsal dark grey with some oblique dark bands, and a large jet black ocellus between third and fourth spines. Second dorsal greyish with narrow bands of longi. tudinal black blotches. Caudal crossed by several or more blackish bars, and the lower margin broadly edged with black. Anal broadly edged with black, but the tips of rays pale.

SexuAl Dimorphism.-In this species, there exist marked sexual difference in the coloration and shape of the fins. This divergence appears to be related to the age of the fish, and becomes conspicuous in $90 \mathrm{~mm}$ in standard length. In the male, the anteriormost two dorsal spines are slender and produced into long filaments, and about twice as long as the head. The four median caudal rays are also very long, the longest of which is often approximately as long as the body exclusive of the caudal. The snout is long and pointed, usually longer than the eye diameter. The lower surface of the body is pale, but a deep brown blotch is placed on the chest.

On the other hand, in the female, the dorsal spines are all short and never produced into filaments, and gradually becoming shorter posteriorly. The four median caudal rays are also elongated, but the longest one is shorter than the body. The

* The averages of counts and measurements are put in parentheses. 
Table 1. Sexual dimorphism found in some proportional measurements in adults of Callionymus japonicus HOUTTUYN.

\begin{tabular}{l|c|c|c|c}
\hline \multicolumn{1}{c|}{ Sex } & \multicolumn{2}{|c|}{ Male } & \multicolumn{2}{c}{ Female } \\
\cline { 2 - 5 } Items & Range & Average & Range & Average \\
\hline In standard length: & $4.0-5.1$ & 4.4 & $4.0-4.9$ & 4.6 \\
Head & & & & \\
In head length: & $2.1-3.4$ & 2.7 & $2.5-3.0$ & 2.9 \\
Snout & $0.6-1.2$ & 0.9 & $1.1-1.2$ & 1.2 \\
1st dorsal spine & $0.6-1.3$ & 0.9 & $1.2-1.5$ & 1.4 \\
2nd dorsal spine & $0.2-0.4$ & 0.3 & $0.3-0.4$ & 0.4 \\
Caudal fin &
\end{tabular}

snout is blunt about as long as the eye diameter. The lower surface of the body is uniformly pale.

Youngs.--In young specimens, the head is rather large, about a fourth of the

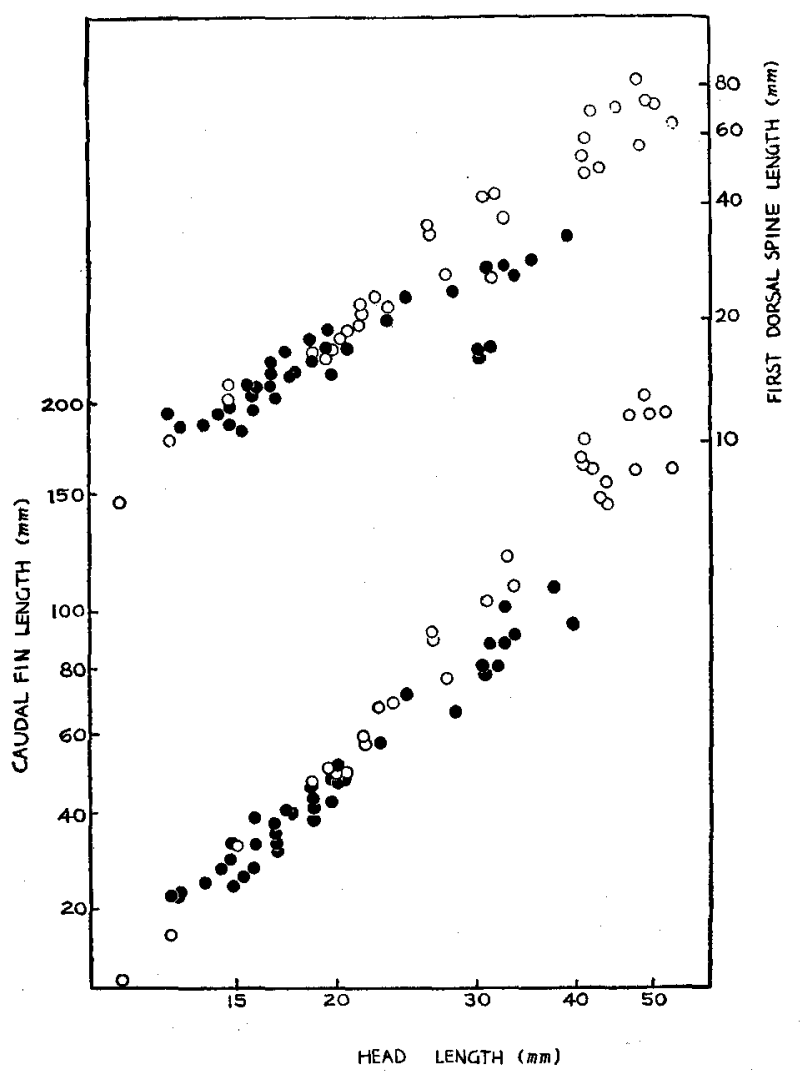

Fig. 1. Dimension of first dorsal spine and caudal fin in Callionymus japonicus HoUTTUYN in relation to the head lengtb. $O$, male. $\bullet$ female. 
standard length. The snout is rather pointed, but shorter than the eye diameter in a very small specimens. The anteriormost two dorsal spines are neither produced nor filamentous even in the male. The caudal fin is rounded, and the longest ray is twice as long as the head. The striated bony crests on the top of the head are more or less inconspicuous, and in the smallest one at our disposal (No. 15043, $36 \mathrm{~mm}$ in standard length) the head is entirely smooth. The under side of the body is uniformly grey.

Table 2. Proportional measurements of several body parts in youngs of Callionymus japonicus HoUTTUYN.

\begin{tabular}{l|c|c|c|c}
\hline \multicolumn{1}{c|}{ Sex } & \multicolumn{2}{|c|}{ Male } & \multicolumn{2}{c}{ Female } \\
\cline { 2 - 4 } Items & Range & Average & Range & Average \\
\hline In standard length: & $3.3-4.5$ & 4.1 & $3.7-4.5$ & 4.1 \\
Head & & & & \\
In head length: & $2.6-4.2$ & 3.5 & $2.4-4.3$ & 3.3 \\
Snout & $1.1-1.6$ & 1.3 & $1.0-1.5$ & 1.2 \\
1st dorsal spine & $1.2-1.4$ & 1.3 & $1.2-1.5$ & 1.4 \\
2nd dorsal spine & $0.4-0.8$ & 0.5 & $0.4-0.6$ & 0.5 \\
Caupal fin & & &
\end{tabular}

REMARKS.--TANAKA's Calliurichthys numeri (1917:7-12) caught at Misaki appears to be nothing more than the female of this species inasmuch as the species in his description agrees perfectly with the present specimens of females in the important features. The present species accords well with Calliurichthys decoratus GrLBERT (1905:651, pl. 90) known from Hawaiian Islands in the general form of the body and coloration on the sides of the body, but presumably be distinguished from it in the general form and color pattern of the first dorsal fin.

\section{Callionymus variegatus TEMMINCK et SCHLEGEL \\ Itohiki-numeri}

Callionymus variegatus.-TEMMINCK et SCHLEGEL, $1845: 153$.

Calliurichthys variegatus.-JORDAN et FOWLER, $1903: 944-945$, fig. 3; FrANz, 1910:84 ; JORDAN, TANAKA et SNYDER, $1913: 373$, fig. 331; IZUKA et MATSUURA, $1920: 109$; UI, $1929: 262$; Chen, $1951: 161$.

Unfortunately no specimens have come under our examination. On going through literature given by TEMMINCK and SCHLEGEL (1845) and JoRdAN and Fowler (1903), this species is closely related to Callionymus japonicus in several important features, but sharply defined from it in several items, thus: dorsal soft rays are always 8 ( 9 in the latter); and soft rays are 7 ( 8 in the latter); preopercular spine is short, always shorter than the diameter of eye (longer than it in the latter); a single broad rugosely striated patch on top of head ( 2 in the latter); soft dorsal is pale and fur- 
nished with alternate wavy lines of grey and black (soft dorsal with narrow bands of longitudinal brown blotches in the latter).

In the male, the anteriormost two dorsal spines are produced into long filaments, but the others are not filamentous. The caudal fin is very long, heavy, while the median ray is the longest, about 0.7 times as long as the body exclusive of the caudal fin. The lower surface of the head is whitish, with a deep brown blotch.

In the female, the dorsal spines are neither elongated nor filamentous, and the caudal fin is short, and the under side of the head white.

\title{
Callionymus doryssus (JORDAN et FOWLER)
}

\author{
Yari-numeri
}

(Fig. 2)

Calliurichthys doryssus.-JORdAN et Fowler, 1903:945-947, fig. 4; SMith et POPE, 1906:493;

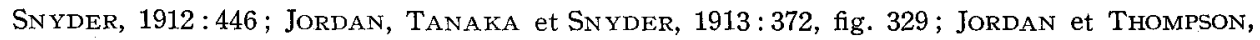
$1914: 294$, fig. 72; JoRdAN et HubBS, 1925:316; UI, $1929: 262$; SchMidt, 1913 b: 141; Kata yama, $1940: 24$; YanaI, $1950: 22$; KUROdA, $1951: 385$; KUROdA, $1952: 174$; MorI, 1952 : 133; KURODA, $1954: 160$.

Material examined.-Male. No. $4691 ; 120 \mathrm{~mm}$ in standard length $(161.5 \mathrm{~mm}$ in total length), Owase, Mie Pref., December 1936. Nos. 18530-18532, 18534-18536, 18538-18543, 1854518546, 18549-18554 and 18556, 96-122.5 mm (154-178 mm), Mimase, Kôchi City, October 1C, 1952. No. 20681, $86 \mathrm{~mm}$ (115 mm), Miya, Aichi Pref., April 10, 1953. Nos. 21938 21940, 21945-21953, $21955-21956,21958-21961,21963-21966,21969,21972-21976,21978,21981-21982,21986,21989-$ 21996, 22000, 22003 and 22005, 53-100 mm (70-142 mm), Mimase, April 10-20, 1954. No. 23065, $118 \mathrm{~mm}(167.5 \mathrm{~mm})$, Yahatahama, Ehime Pref., August 30, 1954. Nos. 23297-23301, 81-125 mm (138-184 mm), off Shibushi, Kagoshima Pref., September 3, 1954.

Female. No. 11292, $61 \mathrm{~mm}(86 \mathrm{~mm})$, Tsuiyama, Hyôgo Pref., April 4, 1949. No. 13948, $94 \mathrm{~mm}(125 \mathrm{~mm})$, Owase, September 20, 1950. No. 15042, $47 \mathrm{~mm}$ (62 mm), Saheki Bay, Ôita Pref., January 3, 1951. No. 15292, $90 \mathrm{~mm}$ (121 mm), Owase, January 15-20, 1950. Nos. 17169 and $17180,79-94.5 \mathrm{~mm}(104-125 \mathrm{~mm})$, Miya, January 8-11, 1951. Nos. 18533, 18537, 18544, 1854718548 and $18555,85-105 \mathrm{~mm}(115-137 \mathrm{~mm})$, Mimase, October 10, 1952 . Nos. 20679-20680, 50$94 \mathrm{~mm}(67-125 \mathrm{~mm})$, Miya, April 10, 1953. Nos. 21383, 21385, 21387 and $21388,65-70 \mathrm{~mm}$ ( $84-$ $88 \mathrm{~mm}$ ), Miya, January 25, 1954. Nos. 21937, 21941-21944, 21954, 21957, 21962, 21967-21968, $21970,21977,21980,21983,21985,21987-21988,21998,22001-22002$ and $22004,48-92 \mathrm{~mm}$ (64$120 \mathrm{~mm}$ ), Mimase, April 10-20, 1954. Nos. 23061-23062, 46-109 mm (59-142 mm), Maizuru, August 26, 1954. Nos, 23064, 23066 and 23067, 98.5-109 mm (128.5-142 mm), Yahatahama, August 30, 1954.

Description.-D. IV, 9 ; A. 9 to $10(9.0)$; P. 18 to 20 (19.2). Head 3.3 to 4.3 (3.8) in standard length; body width 5.6 to 7.7 (6.2); body depth 7.1-12.2 (9.4); depth of caudal peduncle 16.5 to 24.0 (19.3). Snout length 2.3 to 3.4 (3.1) in head length; eye diameter 2.6 to 3.9 (3.1); 4th dorsal spine 2.1 to 5.2 (3.8): 1st dorsal soft ray 1.4 to 2.0 (1.6), 2nd dorsal soft ray 1.5 to 2.1 (1.7); 6th dorsal soft ray 1.3 to 2.5 (1.8); 1st anal ray 2.1 to 3.4 (2.6); pectoral fin 1.1 to 1.6 (1.3); pelvic fin 0.8 to $1.3(1.1)$.

Preopercular spine about as long as eye diameter, the upper edge finely serrated, and the base armed with a spinule directed forward. Upper surface of head entirely 
smooth. Last dorsal soft ray much longer than last anal ray, extending beyond base of caudal in the former, instead of being scarcely reaching it in the latter; the fins, however, never reaching it in the youngs.

SeXual DImorphism.-- Remarkable sexual dimorphism exists in the form of the

Table 3. Sexual dimorphism found in some proportional measurements against head length in adults of Callionymus doryssus (JORDAN et FowLER).

\begin{tabular}{l|c|c|c|c}
\hline \multicolumn{1}{|c|}{ Sex } & \multicolumn{2}{|c}{ Male } & \multicolumn{2}{c}{ Female } \\
\hline Items & Range & Average & Range & Average \\
\hline 1st dorsal spine & $0.4-1.0$ & 0.6 & $0.6-2.0$ & 1.3 \\
2nd dorsal spine & $0.5-1.4$ & 0.7 & $1.0-2.5$ & 1.6 \\
3rd dorsal spine & $0.8-2.1$ & 1.3 & $1.9-2.8$ & 2.2 \\
Last dorsal ray & $0.9-1.5$ & 1.3 & $1.2-1.7$ & 1.4 \\
Caudal fin & $0.5-1.0$ & 0.6 & $0.7-0.9$ & 0.8 \\
\hline
\end{tabular}

fins. This divergence appears to be related to the age of the fish inasmuch as it becomes conspicuous when the fish attains $65 \mathrm{~mm}$ in standard length. In the male, the dorsal spines are long, slender and produced into long filaments, and the anteriormost two spines are especially elongated and much longer than the head. The caudal fin is also elongated, but scarcely twice as long as the head.

In the female, on the other hand, although the dorsal spines are elongated and filamentous, they are much shorter than the head. The caudal fin is moderately long, somewhat longer than the head.

Youngs.-In the youngs, the eye is rather large, and longer than the snout; the last dorsal and anal soft rays are not reaching the base of caudal fin. In the female the dorsal spines are not produced into filaments, but in the male they are more or less elongated.

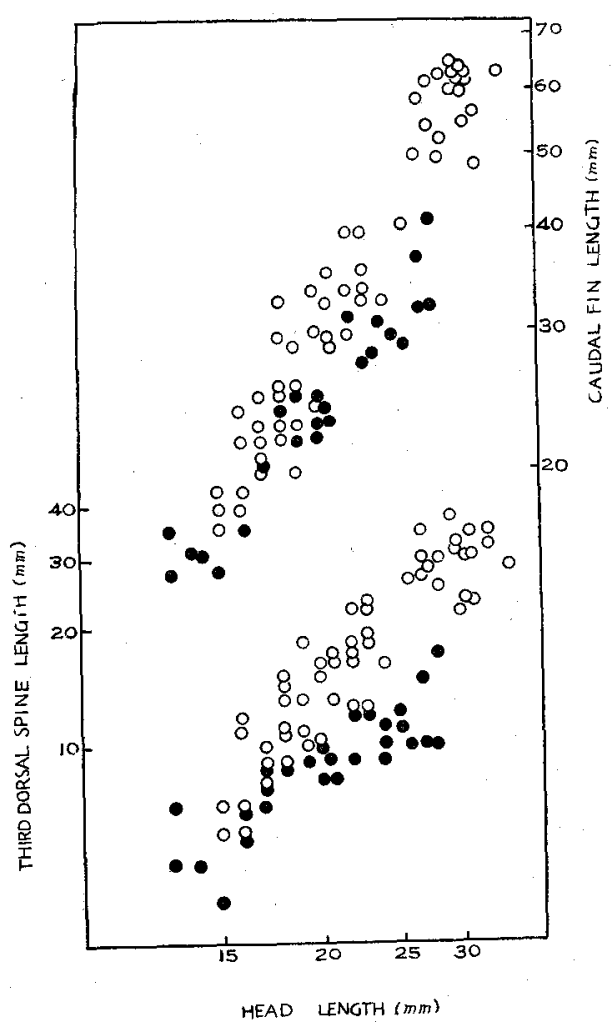

Fig. 2. Dimensions of third dorsal spine and caudal fin in Callionymus doryssus (JORDAN et FOwLER) in relation to head length. $\odot$, male. o, female. 
Table 4. Proportional measurements of dorsal spines, last dorsal ray and caudal fin against head length in youngs of Callionymus doryssus (JORDAN et FowLER).

\begin{tabular}{l|c|c|c|c}
\hline \multicolumn{1}{c|}{ Sex } & \multicolumn{2}{|c|}{ Female } \\
\hline Items & Range & Average & Range & Average \\
\hline 1st dorsal spine & $0.7-1.4$ & 1.0 & $0.8-3.0$ & 1.7 \\
2nd dorsal spine & $0.9-1.8$ & 1.3 & $1.3-3.0$ & 2.2 \\
3rd dorsal spine & $1.2-2.7$ & 1.9 & $1.7-3.8$ & 2.6 \\
Last dorsal ray & $1.3-1.7$ & 1.6 & $1.6-1.9$ & 1.8 \\
Caudal fin & $0.5-0.9$ & 0.8 & $0.7-1.3$ & 0.9 \\
\hline
\end{tabular}

\section{Callionymus calliste JORDAN et FOWLER}

Hanabi-numeri

Callionymus calliste.-JORDAN et Fowler, 1903:954-955, fig. 8 ; JoRdAN, TANAKA et Fowler,

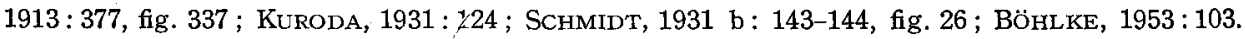

No specimens have come under our examination, but according to the original description and some other comments, this species is characterized in the following points: dorsal soft rays 8 ; anal soft rays 7 ; preopercular spine armed with 3 hooks on the upper margin, and at the base a spinule directed forward; lateral line not connected by a branch with a fellow of opposite side on top of caudal peduncle.

In the male, dorsal spine are long, slender; the first two spines are about equal and a little longer than the base of soft dorsal; the third is longer than either of them; the last is the shortest, although the distal part produced into filamentous. The last dorsal soft ray is reaching the base of caudal when the fin is laid back, but the last anal soft ray extends further behind. The first dorsal fin is grey, dotted with several blackish ocelli at the base, and marked with darker grey lines and spots; the anal fin is greyish white except for the blackish margin and mottled with greyish posteriorly.

In the female, the first two spines of the dorsal are subequal in length, and about equal to 1.6 times in the length of head. The last rays of both dorsal and anal fin are not reaching the base of caudal fin when the fin is depressed. The first dorsal is uniformly blackish; the anal fin is yellow, without any dark markings.

\section{Callionymus phasis GÜNTHER}

\section{Daruma-numeri (new Japanese name)}

(Fig. 3)

Callionymus phasis.-Günther, $1879: 28$, pl. 40, fig. c ; MCCulloch, $1926: 212$; MCCulLOCH, 1929 : 338 ; MCCULLOCH, $1934: 77$; NORMAN, $1937: 56$. 
MAterial EXAmined.-Female. No. $24847,44 \mathrm{~mm}$ in standard length (58 mm in total length), Yahatahama, Ehime Pref., September 10, 1954.

The present species has never heretofore been recorded from the Japanese waters.

Description. -D. IV, 8 ; A. 7 ; P. 18 ; C. 10 . Head 3.5 in standard length; body width 4.9 ; body depth 6.3 ; depth of caudal peduncle 13.7. Snout length 4.0 in head length; eye diameter 3.0 ; interorbital width $12.0 ; 1$ st and 2 nd dorsal spines each 1.8 ; 3 rd dorsal spine $2.0 ; 4$ th dorsal spine $3.4 ; 1$ st and 2 nd dorsal soft rays each $1.4 ; 6$ th and last dorsal soft rays each 1.7 ; 1st anal ray 2.6 ; pectoral fin 1.1 ; pelvic and caudal fins each 0.8 .

Body somewhat elongate and depressed. Trunk broad and tail scarcely tapering backward. Head rather blunt and triangular in upper view. Snout narrow and pointed. Eye very large, close together on top of head. Preopercular spine considerably short, about half as long as eye diameter, terminating in three curved hooks, of which two anterior ones large and directed upwards; a short spinule projecting forward from base of the spine. Gill-opening reduced to a small foramen on the upper side of

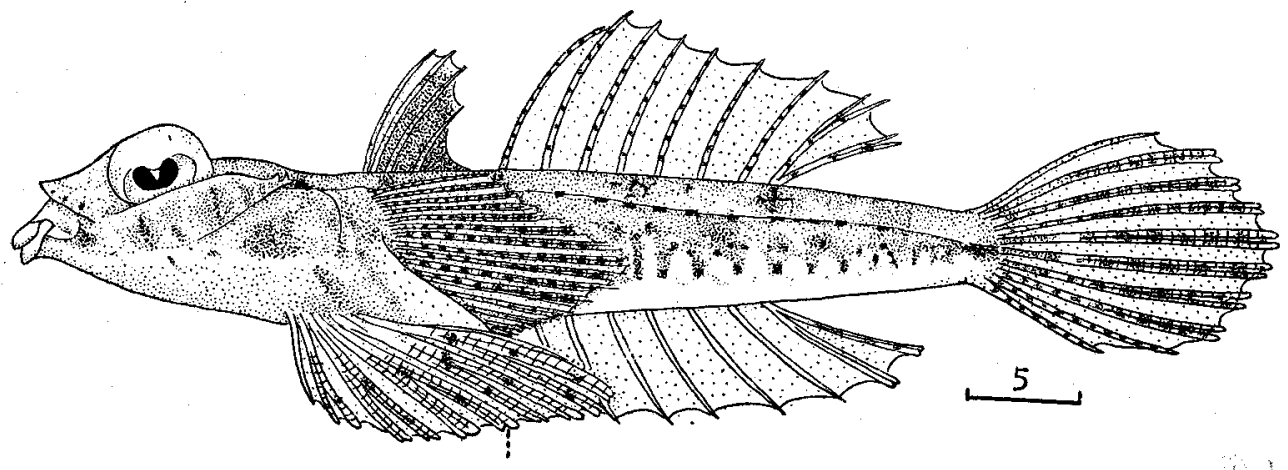

Fig. 3. Lateral view of Callionymus phasis GüNTHER (female) : No. 24847, 44mm in standard length. Drawn by OchIAI.

neck. Lateral line single on each side, each connected on the occiput, but not connected on the upper surface of caudal base.

Dorsal spines rather short and completely connected by membrane, the anteriormost three spines subequal in length and longer than last spine. Soft dorsal rays moderately long, gradually becoming shorter posteriorly. Anal begins under second dorsal soft ray, the rays become higher posteriorly, but the last one not produced and never reaching base of caudal when the fin is depressed. Caudal roundish, the median ray the longest and graduated above and below. Pectoral broad, the rays branched except for the uppermost two. Ventral long, extending beyond origin of anal.

Body olive brown, with several irregular indefinite broad blackish cross bands on back and sides, the lower surface yellow. First dorsal black, narrowly edged anteriorly 
with pale. Pectoral, caudal and second dorsal rays furnished with many black spots in lengthwise series. Anal pale. Ventral scattered with some black spots.

REMARKS.-According to the original description of the present species given by GüNTHER, the male is characterized by the following points: dorsal spines are all prolonged, the first three spines are about as long as the head; the first dorsal fin is blackish with some whitish zig-zag lines; the caudal fin is rather long, the longest ray is longer than the head. GüNTHER indicated in his illustration of this species (pl. 15, fig. c) that the dorsal soft rays are all branched at their tips, but in our single specimen examined the rays are all simple except for the last one.

The present species is closely related to Callionymus lineolatus Cuvier et VALENCIENNES given by DAY (1889: 305, fig. 101), but separable from it in having larger eyes and no remarkable color pattern in the anal fin.

\section{Callionymus planus OchIAI sp. nov.}

\section{Hera-numeri}

(Figs. 4-5)

Holot YPE.- Male. No. 20685, $98 \mathrm{~mm}$ in standard length (125 mm in total length), Miya, Aichi Pref., April 10, 1953.

Paratypes.-Male. Nos. 17163-17166, 89-105 mm (113-135 mm), Miya, January 8-11, 1951. No. 23640, $78.5 \mathrm{~mm}(100 \mathrm{~mm})$, Owase, Mie Pref., October 20, 1954.

Female. Nos. 16960-16961, 96-97 mm (120-122 mm), Miya, September 1951. No. 17167, $87.5 \mathrm{~mm}(118 \mathrm{~mm})$, Miya, January $8-11,1951$. Nos. $21877-21895,41-88 \mathrm{~mm}(51-113 \mathrm{~mm})$, Mimase, Kôchi City, April 15, 1954. Nos. 23638, 23641 and 23642, 73-79 mm (91-100 mm), Owase, October 20, 1954.

Description.-Holotype. D. IV, 9; A. 9; P. 21 ; C. 10 . Head 4.1 in standard length; body width 6.1 ; body depth 10.9 ; depth of caudal peduncle 19.6. Snout length 3.0 in head length; eye diameter 3.4 ; interorbital width $13.3 ; 1$ st dorsal spine 2.0 ; 2nd dorsal spine 3.0 ; 3rd dorsal spine 3.4 ; 4th dorsal spine 4.0 ; 1st dorsal soft ray $1.7 ; 2$ nd dorsal soft ray $1.8 ; 6$ th dorsal soft ray 1.7 ; last dorsal soft ray 1.3 ; 1 st anal ray 2.4 ; pectoral fin 1.0 ; pelvic and caudal fins each 0.9 .

Body elongate and strongly depressed. Trunk broad and flattish. Head very broad and depressed, more than twice as long as deep, and shorter than wide. Snout short and rather pointed. Eye rounded, slightly shorter than snout. Interorbital space flat and somewhat concave, nearly as broad as a quater the diameter of eye. Mouth small and inferior, upper jaw projecting beyond the lower when mouth is closed, and posterior end of maxillary reaching front edge of nostril. Teeth villiform, in broad bands on jaws. Preopercular spine about as long as eye diameter, the upper edge slightly rounded, armed with several rather robust hooks, and the base armed with a sharp spinule directed forward. Gill-opening rounded, nearer origin of dorsal than posterior margin of eye. Lateral line single, with some short branches directed 
obliquely backward and downward; the line connected by a branch with a fellow of opposite side on occiput and on upper surface of caudal base.

First dorsal begins midway between gill-opening and origin of pectoral fin. Dorsal spines not elongated, the first the longest, but not extends to origin of second dorsal when the fin is depressed. Both second and third spines about as long as eye diameter. Fourth spine the shortest. Dorsal soft rays also short and simple except for the last branched and produced one, the tip extends beyond base of caudal fin. Anal fin begins slightly behind a perpendicular through origin of first dorsal ray, and the last one extends beyond base of caudal. Pectoral fin rays branched except for simple two uppermost rays, the median rays the longest, about as long as head. Ventral very long, extending beyond origin of anal. Caudal rounded and slightly longer than head.

Body blackish brown, whitish below; the upper surface rather densely covered with pale spots, surrounded by both numerous small spots and fine reticulation 'of

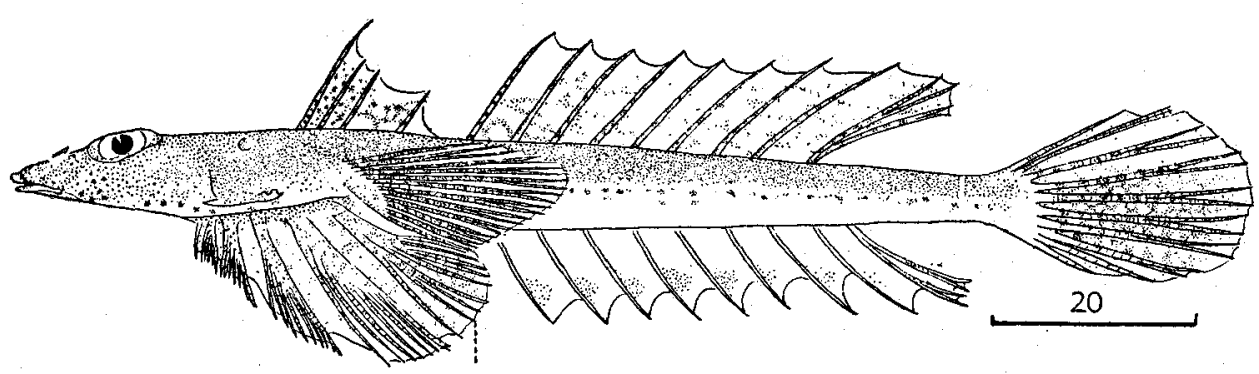

Fig. 4. Lateral view of Callionymus planus. Holotype (male): No. $20685,98 \mathrm{~mm}$ in standard length. Drawn by OchiaI and ARAgA.

darker; the lateral side furnished with many dark specks. Dorsal pale, with fine dark vermiculations. Pectoral pale, but the upper half rays furnished with dark brown spots. Ventral pale, vermiculated with blackish specks. Anal pale, a series of blackish blotches running along the outer margin. Caudal dusky, mottled with minute dark spots, forming dark rings enclosing lighter spots.

Paratype.-D. IV, 9 ; A. 9 ; P. 20 to 21 . Head 4.1 to 4.5 in standard length; body width 6.0 to 6.5 ; body depth 8.7 to 11.2 ; depth of caudal peduncle 18.0 to 22.4 . Snout length 2.6 to 3.3 in head length; eye diameter 2.9 to 3.5 ; interorbital width 9.3 to 15.3 ; 1st dorsal spine 1.8 to 1.9 ; 2nd dorsal spine 2.7 to 3.1 ; 3rd dorsal spine 2.9 to $4.2 ; 4$ th dorsal spine 3.3 to $4.2 ; 1$ st dorsal soft ray 1.5 to $1.8 ; 2$ nd dorsal soft ray 1.5 to 1.9 ; 6 th dorsal soft ray 1.5 to 1.7 ; last dorsal soft ray 0.9 to 1.0 ; 1st anal soft ray 2.4 to 2.9 ; pectoral fin 0.9 to 1.0 ; pelvic fin 0.6 to 0.8 ; caudal fin 0.8 to 0.9 . Color and other characters agree well with those of the holotype. 
Female.-D. 111 to IV, 8 to 10 (9); A. 9 to 10 (9.1); P. 19 to 21 (19.8). Head 3.4 to 4.1 (3.8) in standard length; body width 5.5 to 10.8 (6.4); body depth 8.2 to 13.8 (9.8); depth of caudal peduncle 18.0 to 27.0 (21.4). Snout length 2.9 to 4.3 (3.6) in head length; eye diameter 2.8 to 3.8 (3.2) ; interorbital width 11.0 to 20.0 (14.7); 1st dorsal spine 2.0 to $3.0(2.4)$; 2nd dorsal spine 2.0 to 3.1 (2.5); 3rd dorsal spine 2.6 to $3.8(3.0)$; 4 th dorsal spine 3.4 to $6.5(4.8)$; 1st dorsal soft ray 1.7 to $2.8(1.9)$; 6th dorsal soft ray 1.8 to 2.3 (2.1); last dorsal soft ray 1.5 to 1.9 (1.7); 1st anal ray 2.3 to 3.3 (2.8) ; pectoral fin 1.0 to 1.4 (1.1); pelvic fin 0.7 to 1.4 (1.0); caudal fin 0.9 to $1.1(1.0)$.

Dorsal, anal and caudal fins more or less shorter than those of the males. Colorations of body and fins agree well with those of male except for first dorsal and anal
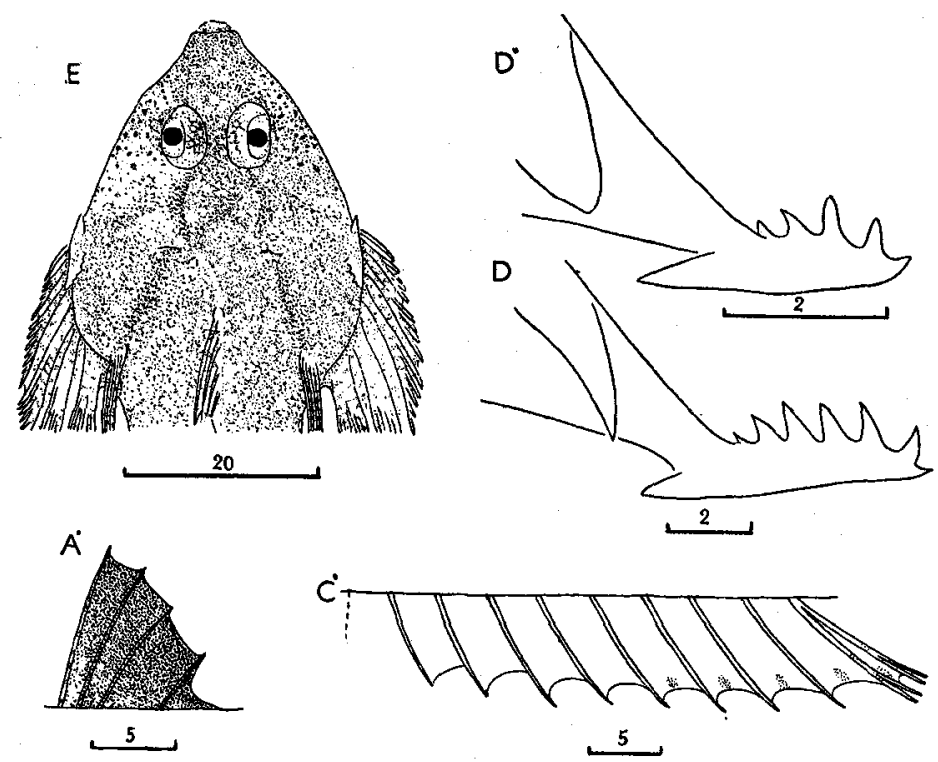

Fig. 5. First dorsal $\left(A^{\prime}\right)$, anal $\left(C^{\prime}\right)$, preopercular spine $\left(D, D^{\prime}\right)$ and dorsal view of the head $(\mathrm{E})$ in Callionymus planus, sp. nov. $\mathrm{A}^{\prime}, \mathrm{C}^{\prime}$ (No. 21893) and $D^{\prime}$ (No. 21914), female; $D$ (No. 21884) and $E$ (No. 20685), male. Drawn by OCHIAI and Araga.

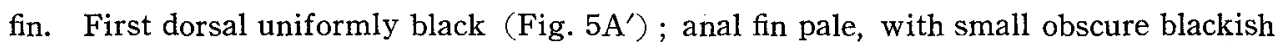
spots (Fig. $5 \mathrm{C}^{\prime}$ ).

REMARKS.--The present new species is easily distinguished from other Japanese species of this group in having wider preopercular spine armed with several robust hooks, and a wider head. The Australian species, Callionymus macdonaldi OGILBY given by McCulloch (1926:205-207, pl. 54, fig. 1) tallies well with the present species, but the top of the head armed with a pair of finely reticulated tubercles (in the latter, the head is largely smooth), and the head is approximately as wide as long (in the latter, the head is much shorter than wide). 


\section{Callionymus sokonumeri KAMOHARA}

Soko-numeri

(Figs. 6-7)

Callionymus sokonumeri--КАMOHARA, $1936: 448$, fig. 2; KAMOHARA, 1938:65-66, fig. 36 ; KAMOHARA, $1952: 90$, fig. 87.

Material eXamined.-Male. No. $18595,112 \mathrm{~mm}$ in standard length (162 mm in total length), Mimase, Kôchi City, October 10, 1952. No. 24779, $89 \mathrm{~mm}(132 \mathrm{~mm})$, Owase, Mie Pref., October 20, 1954. Nos. 25174-25175, 101-107 mm (161 mm-174 mm), Mimase, March 20, 1955.

Female. No. $18178,125 \mathrm{~mm}$ (162 mm), Mimase, October 10, 1952.

Description.-D. IV, 9 ; A. 9 ; P. 18 to 20 ; C. 10 . Head 3.6 to 4.4 in standard length; body width 5.2 to 7.1 ; body depth 8.3 to 9.9 ; depth of caudal peduncle 20.1 to 22.4. Snout length 3.2 to 4.1 in head length; eye diameter 2.1 to 2.9 ; 1 st anal ray 1.9 to 2.5 ; pectoral fin 1.1 to 1.6 ; pelvic fin 0.9 to 1.1 .

Body elongate, moderately depressed and tapering backward. Trunk broad. Head depressed and moderately broad, about as wide as long. Snout rather pointed and much shorter than eye diameter. Eyes large, approaching with each other. Preopercular spine much shorter than eye, with three hooks above, the hindmost of which directed backward and upward, and barbed (Fig. 6). Caudal fin long, the two median rays produced into long filaments, the second as well as the ninth one from the upper also produced, forming a pair of concavity between them and the axial filaments on posterior margin of the fin. Dorsal soft rays elevated, and the middle ones higher than the others, and the last one scarcely reaching base of caudal when the fin is depressed.

Body olive yellow, whitish below; the back with

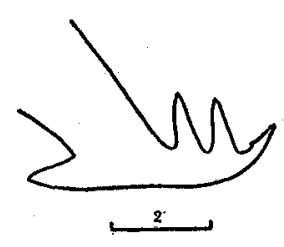

Fig. 6. Preopercular spine in Callionymus sokonumeri KAMOHARA (male): No. 18595, $112 \mathrm{~mm}$ in standard length. Drawn by ARAga. both blackish spots and blotches, the former forming dark rings; the side with a series of several dark brown specks. First dorsal grey, with three oblique dark bands; an irregular blackish blotch placed between third and fourth spines. Second dorsal also grey, with several vertical dark streaks on membranes. Caudal grey, mottled with blackish specks and small whitish blotches. Pectoral pale, the upper part mottled with dark specks. Ventral grey, the inner distal edge conspicuously dark.

SEXUAL DIMORPHISM.--Remarkable sexual dimorphism is found to exist in this species in the coloration and shape of the fin (Table 5). In the male, the dorsal spines moderately elongate, the first spine is the longest, and the tip reaches to or extends beyond the base of the second dorsal soft ray when the fin is depressed. The second dorsal fin is strongly elongated, the longest ray is about as long as or 
much longer than the head. The caudal fin greatly elongated, the two median rays are filamentous, about twice as long as the head. The last soft anal ray scarcely reaches the base of the caudal fin. The anal fin is pale, the distal half is marked with blackish oblique lines running on the membranes between the rays. In our smallest specimen (No. $23779,89 \mathrm{~mm}$ in standard length), however, the fin is pale and broadly edged with black uniformly.

Table 5. Sexual dimorphism in some proportional measurements against head length in Callionymus sokonumeri KAMOHARA.

\begin{tabular}{l|c|c}
\hline Items & Male & Female \\
\hline 1st dorsal spine & $0.9-1.3$ & 1.6 \\
2nd dorsal spine & $1.2-1.4$ & 1.7 \\
3rd dorsal spine & $1.2-1.4$ & 1.8 \\
4th dorsal spine & $1.9-2.7$ & 3.2 \\
1st dorsal soft ray & $0.9-1.2$ & 1.4 \\
2nd dorsal soft ray & $0.8-1.1$ & 1.4 \\
6th dorsal soft ray & $0.7-1.0$ & 1.3 \\
last dorsal soft ray & $0.9-1.3$ & 1.5 \\
Caudal fin & $0.4-0.6$ & 0.8 \\
\hline
\end{tabular}

In the female, the dorsal spines are rather short, the first spine is longer than others, and nearly reaching to the base of the first dorsal soft ray when the fin is laid back. The second dorsal is moderately high, the highest one being a little shorter than the head. The two median caudal rays are the longest, but not filamentous, and slightly longer than the head. The anal fin is also rather high, but the last ray not extending to the base of the caudal fin when the fin is depressed. The fin is pale and more or less edged with dark.

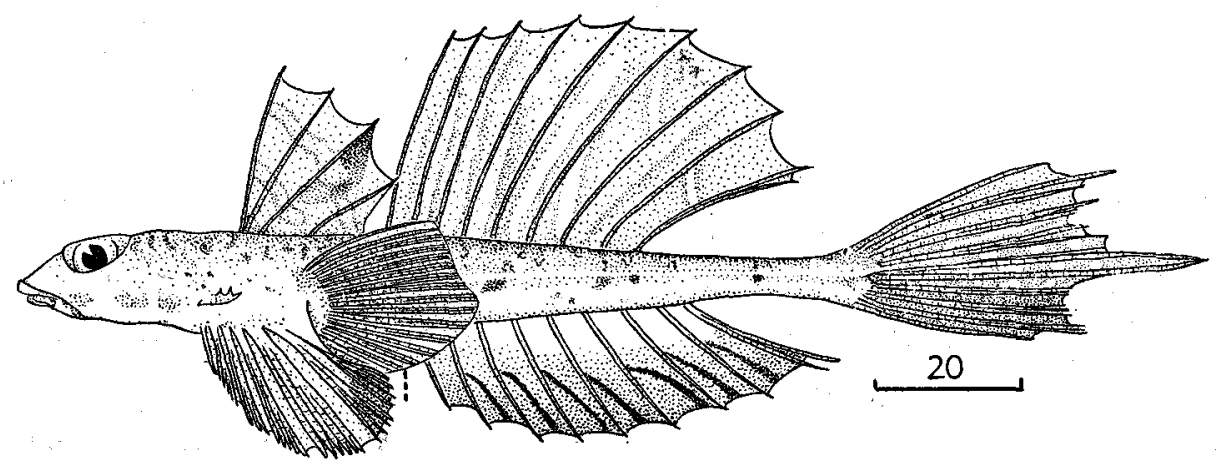

Fig. 7. Lateral view of Callionymus sokonumeri KAMOHARA (male): No. 18595, $112 \mathrm{~mm}$ in standard length. Drawn by OcHIAI. 
REMARKs.--Our male specimens so far examined agree well with the holotype of this species in description (KAMOHARA, 1936, fig. 2) except for the general form of the caudal fin. In the latter, none of the caudal rays, except for the two median filamentous ones, are produced beyond the general contour of the fin.

\section{Callionymus kaianus GüNTHER}

Tongari-numeri (new Japanese name)

(Figs. 8-10)

Callionymus kaianus.-GüNTHER, $1879: 44$, pl. 19, fig. b; AlCOCK, 1899:74; REgAN, $1908: 248$; Beaufort et Chapman, 1951:66-67, fig, 12.

MATERIAL EXAMINED.-Male. Nos. 23259, 23261-23263, 23265-23367, 23269-23270, 2327323276, 23281-23286, 23288-23291 and 23296, 72.5-125 mm (98-171.5 mm), Shibushi, Kagoshima Pref., September 1-3, 1954. Nos. 23778 and 24783, 76-82 mm (102-111.5 mm), Owase, Mie Pref., October 25, 1954.

Female. Nos. 19687-19688, 95-100 mm (129-133 mm), Nobeoka, Miyazaki Pref., December 10, 1952. Nos. 21864, 21866-21868, 21870 and 21873-21876, 38-96 mm (50-126 mm), Mimase, Kôchi City, Apri]. 10-20, 1954. Nos. 23257-23258, 23260, 23262, 23264, 23268, 23271, 23277, 23280 and 23292-23295, 72-123 mm (98-158.5 mm), Shibushi, September 1-3, 1954. No. 23780, $72.5 \mathrm{~mm}$ (95.5 mm), Owase, September 25, 1954.

The present species has never heretofore been reported from our waters.

Description.--D. IV, 9 ; A. 9 ; P. 18 to 21 (19.5) ; C. 10 . Head 3.5 to 4.4 (4.1) in standard length; body width 5.9 to 8.6 (6.8); body depth 7.8 to 13.1 (10.2); depth of caudal peduncle 19.3 to 31.0 (25.6). Snout length 2.8 to 4.0 (3.3) in head length; eye diameter 2.3 to 3.0 (2.6); interorbital width 14.5 to 29.0 (21.9); 1st dorsal soft ray 1.2 to $1.9(1.5) ; 2$ nd dorsal soft ray 1.2 to $1.8(1.5)$; 6 th dorsal soft ray 1.2 to 2.2 (1.5); 1st anal ray 2.2 to 3.6 (2.7); pectoral fin 1.0 to $1.6(1.3)$; pelvic fin 0.9 to $1.5(1.1)$.

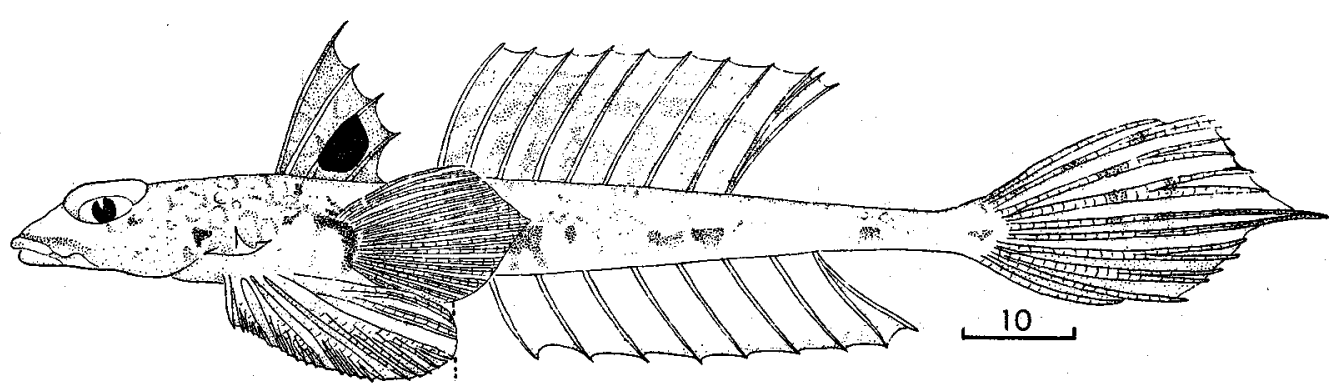

Fig. 8. Lateral view of Callionymus kaianus GÜNTHER (male): No, 23274, $91 \mathrm{~mm}$ in standard length. Drawn by OchIAI. 


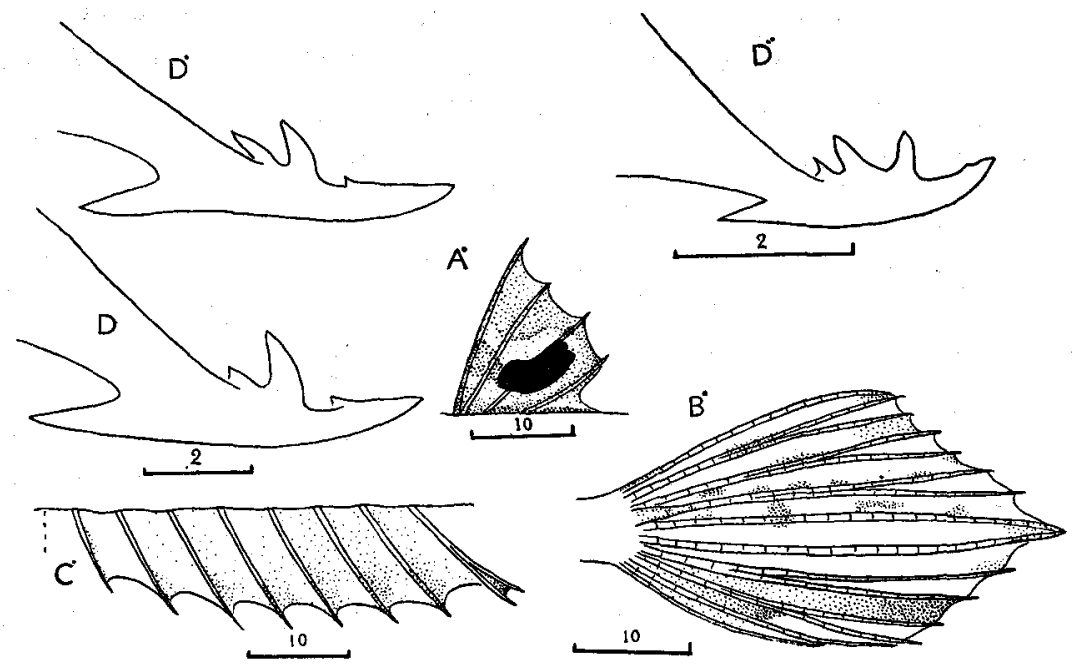

Fig. 9. First dorsal $\left(\mathrm{A}^{\prime}\right)$, caudal $\left(\mathrm{B}^{\prime}\right)$, anal fin $\left(\mathrm{C}^{\prime}\right)$ and preopercular spines $\left(\mathrm{D}, \mathrm{D}^{\prime}, \mathrm{D}^{\prime \prime}\right)$ in Callionymus kaianus GỨNTHER. D (No. 23283), male ; $\mathrm{A}^{\prime}, \mathrm{B}^{\prime}, \mathrm{C}^{\prime}$ (No. 23294), $D^{\prime}$ (No. 23257) and $D^{\prime \prime}$ (No. 21867), female. Drawn by Ochiai and ARAGA.

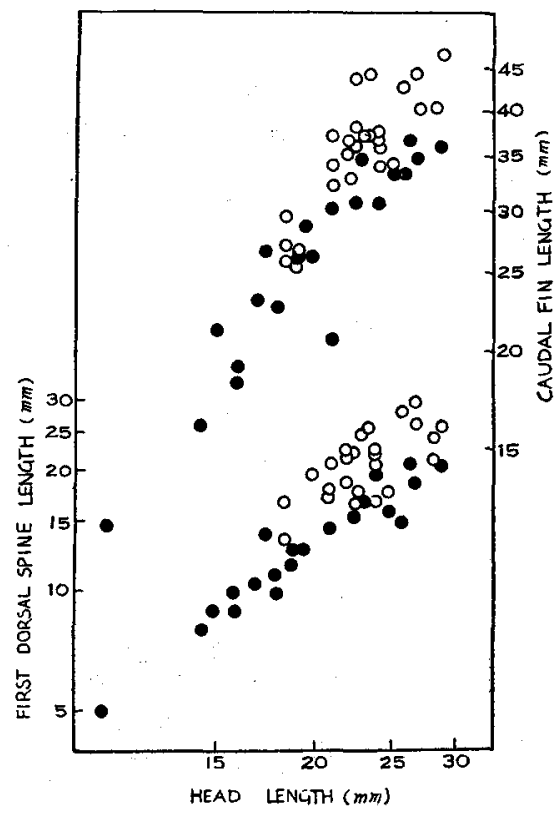

Fig. 10. Dimentions of first dorsal spine and caudal fin length in Callionymus kaianus GüNTHER in relation to head length. $O$, male. female.
Body elongate, moderately depressed and tapering backward. Trunk broad. Head depressed, about as broad as long. Snout short and narrow, conspicuously shorter than eye diameter. Eyes large, narrowly separated from each other. Preopercular spine shorter than eye, armed with three or four hooks above, the hindmost one of which barbed; a spinule directed forward from base of preopercular spine (Fig. 9D, D'). Gill-opening reduced to a small foramen on each side of neck. Lateral line single, connected by a branch with a fellow of opposite side on occipital region and also on upper surface of caudal base. Dorsal and anal soft rays moderately high, the last one never reaching base of caudal when the fins are depressed.

Body brownish yellow above, whitish below; the back with minute blackish spots, forming rings and blotches; the sides crossed by several dark brown blotches and with many irregular faint specks. First dorsal 
grey, with a large conspicuous blackish blotch between third and fourth spines. Second dorsal grey, ornamented with large irregular dark blotches and submarginal dark bands. Caudal pale except for darker lower part, where the fin is scattered with several pearl-white round spots. Anal dusky, sometimes indefinitely but broadly edged with black. Pectoral uniformly pale. Ventral pale, but the outer posterior margin more or less dark.

SEXUAL DIMORPHISM.--Remarkable sexual dimorphism exists in the form of fins in this species. It appears to be related to the age of the fish, inasmuch as it becomes conspicuous when the fish attains $82 \mathrm{~mm}$ in standard length. In the male, the first dorsal spine is produced into filament which is about as long as the head. The two median caudal rays are also produced and much longer than the others, and about 1.5 times as long as the head length. On the other hand, in the female, the first dorsal spine is scarcely longer than the second or third spine, and much shorter than the head. (Fig. 9A') The two median caudal rays are more or less longer than the others, and about 1.2 times as long as the head length. (Fig. 9B')

YounGs. - The hindmost hook on the preopercular spine is scarcely barbed in some youngs (Fig. 9D"). The first and fourth dorsal spines of the young males are a little longer than those of the young females.

REMARKS.-The present species is closely related to Callionymus sokonumeri KAMOHARA at least in having large eyes, elongated fins, the barbed hindmost preopercular hook and the peculiar coloration of the body, but they can sharply be separated from each other in the length and coloration of the vertical fins.

Table 6. Proportional measurements of dorsal spines, last dorsal soft ray and caudal fin against head length in adults (upper column) and youngs (lower column) of Callionymus kaianus GünTHER.

\begin{tabular}{l|c|c|c|c}
\hline \multirow{2}{*}{ Sex } & \multicolumn{2}{|c|}{ Male } & \multicolumn{2}{c}{ Female } \\
\cline { 2 - 5 } & Range & Average & Range & Average \\
\hline 1st dorsal spine & $0.9-1.4$ & 1.1 & $1.2-1.8$ & 1.5 \\
2nd dorsal spine & $1.4-1.9$ & 1.7 & $1.6-1.9$ & 1.7 \\
3rd dorsal spine & $1.2-2.2$ & 1.8 & $1.7-1.9$ & 1.7 \\
4th dorsal spine & $2.2-3.4$ & 2.8 & $2.5-3.2$ & 2.6 \\
Last dorsal ray & $1.2-1.5$ & 1.3 & $1.2-1.6$ & 1.3 \\
Caudal fin & $0.5-0.8$ & 0.7 & $0.7-1.0$ & 0.8 \\
\hline 1st dorsal spine & $1.1-1.6$ & 1.4 & $1.0-2.2$ & 1.6 \\
2nd dorsal spine & $1.6-1.8$ & 1.7 & $1.5-2.2$ & 1.8 \\
3rd dorsal spine & $1.7-2.0$ & 1.9 & $1.7-2.6$ & 2.1 \\
4th dorsal spine & $2.6-3.5$ & 3.0 & $2.6-5.5$ & 3.7 \\
Last dorsal ray & $1.3-1.6$ & 1.4 & $1.3-3.0$ & 1.9 \\
Caudal fin & $0.6-0.7$ & 0.7 & $0.7-0.9$ & 0.8 \\
\hline
\end{tabular}




\title{
Callionymus flagris JORDAN et FOWLER
}

\author{
Hatatate-numeri
}

(Fig. 11)

\begin{abstract}
Callionymus fiagris.--JoRdan et Fowler, 1903:952-954, fig. 7; JoRdAN et STARKS, 1904:598, fig. 1; Franz, 1910:84; SNYDER, 1912:447; Jordan, TANAKA et SNYDER, 1913:379, fig. 335 ; UI, $1929: 261$; KURODA, $1931: 124$; BÖHLKE, $1953: 103$.

Callionymus valenciennesi (not of TEMMINCK et SCHLEGEL).-JoRDAN et HUBBS, $1925: 317-318$;

SchmidT, 1931:122; TANAKA, 1931:40; KaMohara, 1938:65; Fowler, 1941:22-23;

KAMOHARA, $1952: 90$.
\end{abstract}

Material examined.-Male. No. 794, $103 \mathrm{~mm}$ in standard length (148 $\mathrm{mm}$ in total length), locality unknown. Nos. 10280-10284, 83-89 mm (125-137 mm), Obama, Fukui Pref., June 17, 1948. No. $17018,65 \mathrm{~mm}(86 \mathrm{~mm})$, Shimonoseki, March 9, 1951. Nos. $2210222103,90-94 \mathrm{~mm}$ (129$138 \mathrm{~mm}$ ), Toyohama, Mie Pref., February 17, 1954. Nos. (Hokkaido Univ. Fish Coll.) 5438, 5441, 5443 and 5445, 70-100 mm (102-146 mm), Asamushi, Aomori Pref.

Female. No. $1259,77 \mathrm{~mm}(100 \mathrm{~mm})$, Owase, December 6-9, 1935 . No. $1737,99 \mathrm{~mm}(129 \mathrm{~mm})$, Owase, January 4-8, 1936. Nos. 10279 and 10285-10290, 64-86 mm (84-112 mm), Obama, June 17, 1948. No. 16557, $68 \mathrm{~mm}(88 \mathrm{~mm})$, Kunda, Ky ôto Pref., June 1, 1951. Nos. (Hokkaido Univ. Fish Coll.) $5439-5440$ and $5442,75-79 \mathrm{~mm}(96.5-120 \mathrm{~mm})$, Asamushi.

Description.-D. IV, 7 to 9 (8.8); A. 9 to 10 (9.1); C. 10 . Head 3.7 to $4.4(4.0)$ in standard length; body width 5.7 to 9.5 (6.6); body depth 7.8 to 11.3 (9.5) ; depth of caudal peduncle 15.8 to 22.6 (19.4). Snout length 2.8 to 4.0 (3.1) in head length: eye diameter 2.6 to 3.6 (3.1); 1st dorsal ray 1.2 to $1.8(1.3)$; 2 nd dorsal ray 0.7 to 1.7 (1.3); 1st anal ray 2.3 to 3.6 (3.1); pectoral fin 1.0 to 1.3 (1.1); pelvic fin 0.8 to $1.1(1.0)$.

Preopercular spine very short, about half as long as eye diameter, with three or four sharp hooks above, of which hindmost one directed upward and backward, but the others upward and forward; a sharp spine directed forward at the base of the spine (Fig. 11D, D').

SeXuAl dimorPhism.-The present species shows also remarkable secondary sexual dimorphism in the coloration and the length of the fins (Table 7, fig. 11). So far as our observations go, such differences become significant at least when the fish attains $60 \mathrm{~mm}$ in standard length.

In the male, the dorsal spines are all greatly elongated except for the second one, and produced into filaments; the first spine is the longest, sometimes extends to the base of the caudal fin when the fin is depressed, the second spine is the shortest and usually shorter than the head, the third and fourth spines are more or less longer than the head. The last dorsal soft ray is long, extending beyond the base of the caudal fin when the fin is laid back. The caudal fin is also elongated, the several median rays are produced into slender filaments beyond the general contour of the fin-membrane, and the longest one is about twice as long as the head (Fig. 11B). The last anal ray also extends to the base of the caudal peduncle. The first dorsal 
fin is grey, provided with many whitish lines, dark spots and a blackish marginal crescentic blotch (Fig. 11A). Two or three rows of large blackish spots are set in lengthwise series on the base of the second dorsal fin. The anal fin is grey, becoming darker towards the outer margin (Fig. 11C).

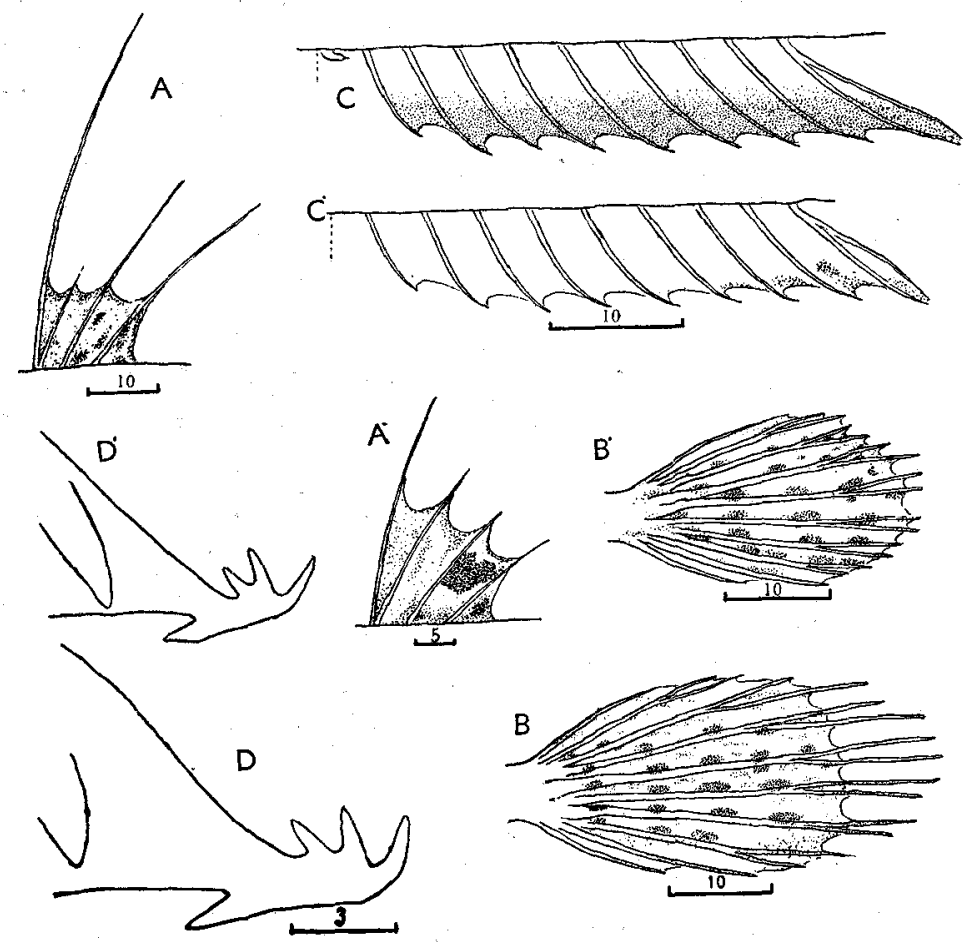

Fig. 11. First dorsal (A, $\left.A^{\prime}\right)$, caudal $\left(B, B^{\prime}\right)$, anal $\left(C, C^{\prime}\right)$ and preopercular spine $\left(\mathrm{D}, \mathrm{D}^{\prime}\right)$ in Callionymus flagris JORDAN et FowLER. A, B, C (No. 22103) and D (No. 172), male; A', B', C' (No. 22101) and $D^{\prime}$ (No. 169), female. Drawn by Araga.

Table 7. Proportional measurements of spines and rays against head length in Callionymis fragris JORDAN et FOWLER.

\begin{tabular}{l|c|c|c|c}
\hline \multirow{2}{*}{ Items } & \multicolumn{2}{|c|}{ Male } & \multicolumn{2}{c}{ Female } \\
\cline { 2 - 5 } & Range & Average & Range & Average \\
\hline 1st dorsal spine & $0.4-0.7$ & 0.5 & $1.2-1.6$ & 1.4 \\
2nd dorsal spine & $0.7-1.8$ & 1.3 & $1.6-2.3$ & 1.8 \\
3rd dorsal spine & $0.5-1.2$ & 0.8 & $1.6-2.4$ & 2.0 \\
4th dorsal spine & $0.5-1.0$ & 0.8 & $2.1-2.8$ & 2.5 \\
6th dorsal ray & $1.2-1.5$ & 1.3 & $1.4-2.0$ & 1.7 \\
Last dorsal ray & $0.6-1.0$ & 0.8 & $1.3-1.9$ & 1.6 \\
Caudal fin & $0.5-0.6$ & 0.5 & $0.4-0.9$ & 0.8 \\
\hline
\end{tabular}


In the female, the dorsal spines are more or less filamentous and the first spine extends to the base of the second dorsal ray when the fin is depressed (Fig. 11 $\mathrm{A}^{\prime}$ ). The last dorsal and anal rays are rather short, never reaching to the base of the caudal fin when the fins are depressed. The caudal rays are but little produced into filaments, and the longest one is slightly longer than the head (Fig. 11B'). The first dorsal fin is grey, provided with several irregular black blotches, of which the one laid between the third and fourth spines is larger and darker than the others (Fig. 11A'). The blackish brown spots on the second dorsal are smaller than those of the male. The anal fin is pale except for the dark margin on posterior part of the fin (Fig. $11 \mathrm{C}^{\prime}$ ).

REMARKs.--Many authorities have accepted Jordan and HubBs' view (1925:317) that $C$. valenciennesi TEMminck et SchLEGEL is erroneously renamed as a new species, C. flagris by JORDAN and Fowler (1903:952-954). However, the male of C. valenciennesi is obviously distinguished from that of the present species at least in having moderately elongated but shorter dorsal spines, the first spine being equal to the second in length. The last dorsal and anal soft rays are also shorter in the former, and never extend to the base of the caudal fin. In addition to these facts the caudal fin rays in the former are never filamentous, and the longest one is but slightly longer than the head.

\section{Callionymus punctatus LANंGSDORFF}

Nezumi-gochi

(Fig. 12)

Callionymus punctatus.-RICHARDSON, $1846: 210$.

Callionymus richardsoni.-BLEEKER, 1854:414; JORDAN et HUBBS, $1925: 317$; SCHMIDT et LINDBERG, $1930: 1150$; SCHMIDT, 1931 a : 122; SCHMIDT, 1931 b: 143; TANAKA, $1931: 40$; KuRODA, 1951 : 386 ; HoNMA, $1952: 225$.

Callionymus curvicornis.-GüNTher, 1861:145; IshIKawa et MatsuURA, $1897: 37$; SEALE, $1914: 79$.

Callionymus valenciennesi.-JORDAN et FOWLER, 1903:950-952, fig. 6; JoRDAN et STARKS, 1905: 211 ; SMJth et Pope, $1906: 493$; SNyder $1912: 447$; JoRdAN et METz, $1913: 59$, fig. 59; JoRDAN, TANAKA et SNYDER, 1913:374-375, fig. 333; JoRdAN et THOMPSON, $1914: 293-294$; MORI, $1928: 8$; UT, $1929: 261$; KAMAHORA, $1936: 4$; KoIKe, 1936:13; KATAYAMA, 1940:24 ; BOESEMAN, $1947: 131-133$; ChEN, $1951: 161$; MORT, $1952: 132$.

MAterial EXAMined,-Male. No. $4693,151 \mathrm{~mm}$ in standard length (222 mm in total length), Owase, Mie Pref., December 1936. Nos. 11537-11538, 100-107 mm (135-152.5 mm), Chôshi, Chiba Pref., May 3, 1947. No. 12079, $135 \mathrm{~mm}$ (199 mm), Niigata, January and February, 1950. No. 15037, $154 \mathrm{~mm}$ (218 mm), Saheki Bay, Ôita Pref., January 3, 1951. Nos. 17080-17081, 136.5-142 mm (202-208 mm), Shimonoseki, September 26, 1950. No. 18599, $105 \mathrm{~mm}$ (146 mm), Mimase, Kôchi City., October 10, 1952. No. 19284, 104 mm (145 mm), Yôrô, Kyôto Pref., October 29, 1952. No. $21364,118 \mathrm{~mm}(167 \mathrm{~mm})$, lacality unknown. Nos. 21863-21865, 84-95 mm (112$131 \mathrm{~mm}$ ), Mimase, April 10-20, 1954. Nos. 22082-22086, 136-152 mm (189-215 mm), Yorijima, Okayama Pref., March 3, 1954. Nos. 22092-22098, 22109 and 22115, 121-155 mm (159-209 mm), 
Toyohama, Mie Pref., February 17, 1954. Nos. 23636-23637, 107-121 mm (152.5-163 mm), Yahatahama, Ehime Pref., October 10, 1954 . Nos. 25092-25093, 141-142 mm (205.5-208 mm), Hakodate.

Female. No. 4606, $54 \mathrm{~mm}$ (68 mm), Kumanonada, October 20, 1936. No. 4699, $130 \mathrm{~mm}$ $(175 \mathrm{~mm})$, Owase, January 3, 1937. No. 7738, $152 \mathrm{~mm}(200 \mathrm{~mm})$, Chôshi, February 16, 1944. No. 10250, $168 \mathrm{~mm}$ (226 mm), Hamada, Shimane Pref., May 13, 1948. No. 11538, $121 \mathrm{~mm}$ (156 mm), Chôshi, May 3, 1949. Nos. 16552, 16555 and 16556, 50-87 mm (65-115 mm), Kunda, June 1, 1951. No. $16815,88 \mathrm{~mm}(115 \mathrm{~mm})$, Ôsaka Bay, October 1950. No. 16962, $98 \mathrm{~mm}$ (132 mm), Miya, Aichi Pref., September 1951. Nos. 17077 and 17079, 86-90 mm (115-117 mm), Shimonoseki, June 11, 1951. No. 17168, $90 \mathrm{~mm}$ (117 mm), Miya, January 9-11, 1952. Nos. 18590-18591, 106-124 mm (142-168 mm), Mimase, October 10, 1952. No. 18796, $83 \mathrm{~mm}$ (108 mm), Yôrô, October 29, 1952. No. $20370-20371,131-138 \mathrm{~mm}$ (177-179 mm), locality unknown. No. 20682, $118 \mathrm{~mm}(154 \mathrm{~mm})$, Miya, April 10, 1953. No. 21365, $42 \mathrm{~mm}(54 \mathrm{~mm})$, locality unknown. Nos. 21382 and 21386, 83$85 \mathrm{~mm}$ (103-110 mm), Miya, January 25, 1954. Nos. 22087-22091, 140-165.5 mm (184-217 mm), Yorijima, May 30, 1954. Nos. 22099, 22105-22108 and 22110-22114, 110.5-159 mm (144-215.5 mm), Toyohama, February 17, 1954. No. 23069, $131 \mathrm{~mm}(180 \mathrm{~mm})$, Yahatahama, August 30, 1954 . No. 23635, $100 \mathrm{~mm}$ (131 mm), Yahatahama, October 10, 1954. No. 24846, $104 \mathrm{~mm}$ (140 mm), Owase, October 25, 1954. Nos. (Hokkaido Univ. Fish Coll.) 5414-5417 and other two specimens, 68$135 \mathrm{~mm}(92-187 \mathrm{~mm})$, Hakodate.

Description.-D. IV, 8 to 10 (9.0); A. 8 to $10(9.0)$; P. 17-22 (19.2); C. 10 . Head 3.5 to 4.8 (4.2) in standard length; body width 5.6 to $8.4(6.6)$; body depth 8.4 to 11.8 (9.7) ; depth of caudal peduncle 16.7 to 23.9 (19.6). Snout length 1.8 to 3.9 (2.7) in head length; eye diameter 1.8 to 4.4 (3.6); 1st and 2nd dorsal soft rays each 1.1 to 1.8 (1.5) ; 6th dorsal soft ray 1.0 to $2.0(1.5)$; 1 st anal ray 1.9 to $3.1(2.5)$; pectoral fin 0.8 to 1.5 (1.2); pelvic fin 0.7 to 1.2 (1.0).

Snout rather pointed, somewhat longer than eye diameter. Preopercular spine long, nearly as long as eye diameter, with three or four hooks above, and an antrorse spinule at the base (Fig. 12D, $D^{\prime}$ ). The last dorsal and anal soft rays reach to or extend beyond base of caudal fin. The dorsal spines short, not filamentous. The caudal fin long, the median rays the longest, but the upper three rays remarkably shorter than the others (Fig. 12B, $\mathrm{B}^{\prime}$ ).

SExuAl DImorphism.--Remarkable sexual dimorphism is also found to exist in this species in several external characters (Table 8, fig. 12). The difference becomes significant when the fish attains $95 \mathrm{~mm}$ in standard length.

In the male, the dorsal spines are subequal with each other in length except for the first one which is a little longer than the others (Table 8). The last dorsal ray extends beyond the base of the caudal fin by a distance approximately equal to the eye diameter. The caudal fin is greatly elongated in the median part, and about twice as long as the head length (Fig. 12B). Numerous light brown streaks run obliquely downward and forward on the sides of the body (Fig. 12C). The first dorsal is grey, with several irregular dark brown blotches, of which the one laid between the third and fourth is darker than the others, and sometimes it is even black. The membrane between the first to fourth dorsal spines is narrowly edged with black (Fig. 12A). The anal fin is grey, and broadly edged with black (Fig. 12C). 
In the female, the first three dorsal spines subequal with each other, but the hindmost one is shorter than the others. The last dorsal ray reaches to or extends more or less beyond the base of the caudal fin. The caudal fin.is shorter than in the male, but much longer than the head (Fig. 12B'). The lateral and under sides of the body and the anal fins are all uniformly pale (Fig. $12 \mathrm{C}^{\prime}$ ). The first dorsal is grey, with irregular dark blotches, and ocellated with black on the membrane between the third and fourth spines (Fig. 12A').

There are some interesting male specimens (Nos. 18599, 22092 and 22115) which reveal female features in the coloration of the first dorsal fin. Their fin is not edged
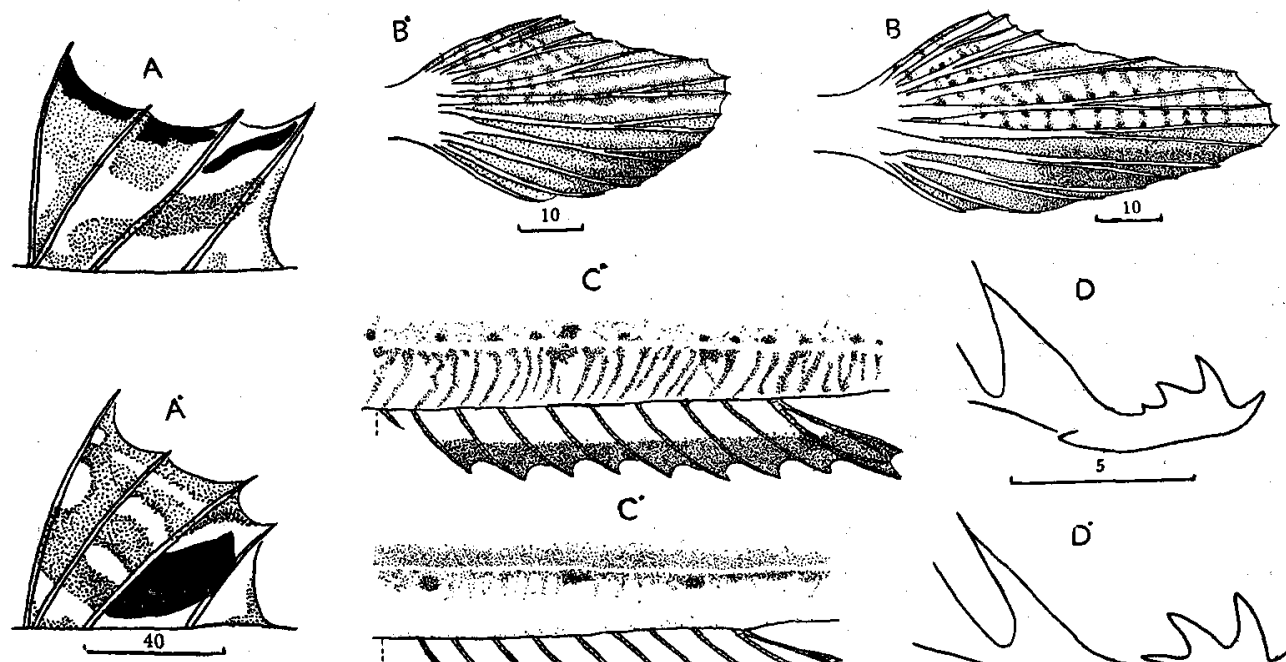

\section{$c^{\circ}$}

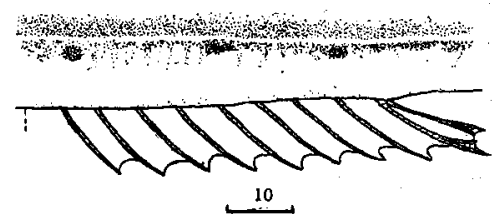

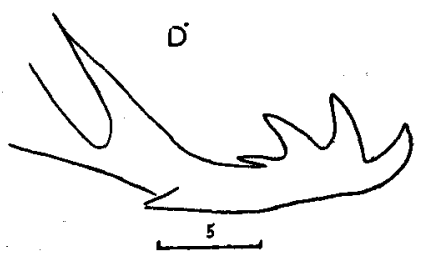

Fig. 12. First dorsal $\left(A, A^{\prime}\right)$, caudal $\left(B, B^{\prime}\right)$, anal $\left(C, C^{\prime}\right)$ and preopercular spine $\left(D, D^{\prime}\right)$ in Callionymus punctatus LANGsdorfF. A, B, C (No. 22083) and D (No, 19274), male ; A', B', $\mathrm{C}^{\prime}$ and $D^{\prime}$ (No. 23071), female. Drawn by Ochial and ARAGA.

Table 8. Sexual dimorphism found in some proportional measurements against head length in adults of Callionymus punctatus LANGSDORFF.

\begin{tabular}{l|c|c|c|c}
\hline \multirow{2}{*}{ Sex } & \multicolumn{2}{|c|}{ Male } & \multicolumn{2}{c}{ Female } \\
\cline { 2 - 5 } Items & Range & Average & Range & Average \\
\hline 1st dorsal spine & $1.4-1.9$ & 1.6 & $1.4-2.2$ & 1.7 \\
2nd dorsal spine & $1.7-2.4$ & 2.1 & $1.4-2.1$ & 1.8 \\
3rd dorsal spine & $1.5-2.5$ & 1.9 & $1.2-2.3$ & 1.7 \\
4th dorsal spine & $1.4-3.3$ & 2.1 & $1.5-3.1$ & 2.5 \\
Last dorsal ray & $0.7-1.2$ & 0.9 & $0.7-1.2$ & 1.0 \\
Caudal fin & $0.5-0.7$ & 0.6 & $0.5-0.8$ & 0.7 \\
\hline
\end{tabular}


with black but ocellated with black between the third and fourth spines as is the case with the female.

YounGs.--In the youngs, the dorsal spines, the last dorsal soft ray and the caudal fin are all much shorter than those of the adult. The first dorsal fin is always provided with a large black ocellus, but not edged with black.

REMARKS.-The observation of the first dorsal spine made by JORDAN and HuBBs (1925:317) agrees well with ours. In the female, the ocellus persists throughout life, but in the male it usually disappears, being gradually replaced by a black border on the fin and both the ocellus and black border exist together in the half-grown and even occasionally in the large adult male.

It is also pointed out by Boeseman (1947: 131-133) that the fishes, Nos. 1011, 2079b and 2079c described as $C$. valenciennesi by Temminck and Schlegel, belong to the present species.

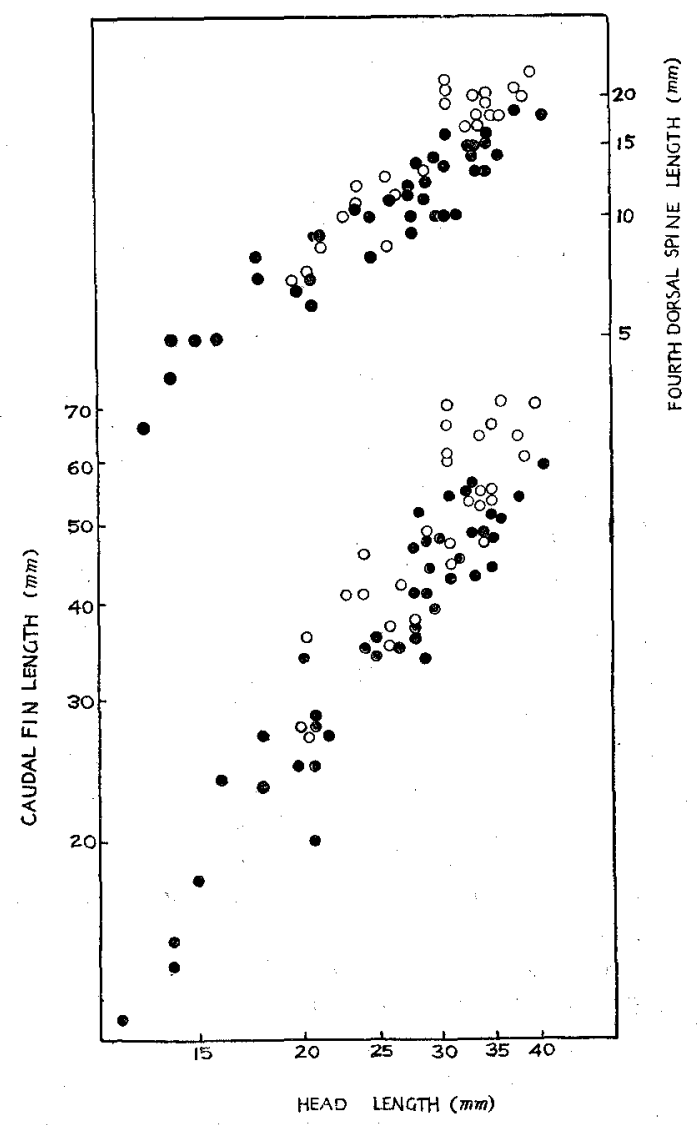

Fig. 13. Dimentions of 4 th dorsal spine and caudal fin in Callionymus punctatus LANGSDORFF in relation to the head length. $O$, male. female.

Table 9. Proportional measurements of several body parts against head length in youngs of Callionymus punctatus LANGSDORFF.

\begin{tabular}{l|c|c|c|c}
\hline \multicolumn{2}{c|}{ Sex } & \multicolumn{2}{|c|}{ Male } & \multicolumn{2}{c}{ Female } \\
\cline { 2 - 5 } Items & Range & Average & Range & Average \\
\hline 1st dorsal spine & $1.8-1.9$ & 1.8 & $1.8-3.0$ & 2.1 \\
2nd dorsal spine & $2.1-2.3$ & 2.2 & $1.8-3.0$ & 2.0 \\
3rd dorsal spine & $2.0-2.5$ & 2.3 & $1.6-3.2$ & 2.2 \\
4th dorsal spine & $2.5-3.0$ & 2.8 & $2.3-6.0$ & 3.4 \\
Last dorsal ray & $0.8-1.1$ & 1.0 & $1.1-2.0$ & 1.4 \\
Caudal fin & $0.6-0.8$ & 0.7 & $0.7-1.1$ & 0.8 \\
\hline
\end{tabular}




\title{
Callionymus lunatus TEMMINCK et SCHLEGEL
}

\author{
Nezuppo: Numeri-gochi
}

(Figs. 14-15)

\begin{abstract}
Callionymus lunatus.-TeMminck et SCHLEGEL, $1845: 155$, pl. 78, fig. 4 ; GÜNTHER, $1861: 146$; GÜNTHER, $1879: 28,67-68$; Jordan et Fowler, 1903:949-950, fig. 5: Jordan et Starks, 1904 : 598; Regan, $1905: 24-25$; Smith et Pope, $1906: 493$; Franz, 1910:84; SNyder, 1912 : 446; Jordan, TANAKA et SNyder, 1913:374, fig. 332; Jordan et ThOmpson, 1914:294, fig. 70 ; Jordan et HUbBS, $1925: 316-317$; MORI, $1928: 8$; UI, $1929: 225$; SCHMIDT, $1930: 1150$; KURODA, 1931:124; NAKAMURA, 1934:25; MORI et UCHIDA, 1934:21; KolKe, 1936:13; Kamohara, $1938: 65$; Boeseman, $1947: 133$; Mako, $1949: 134$; Katayama, $1950: 10$; Chen, $1951: 161$; Honma, $1952: 225$; Kamohara, $1952: 90$; MoRI, $1952: 132$.

Callionymus lunatus form lunatus.-KURODA, $1951: 386$.

Callionymus lunatus form usuiro.-KURODA, $1951: 386$; KURODA, 1952: 173-174.
\end{abstract}

MATERIAL EXAMINED.-Male. Nos. 748-780, 782-785, 787-794, 795-810, 812-828, 830-848, 850, 852-855 and 857-867, 91-137 mm (121-186 mm), locality unknown. Nos. 5483-5486, 122$130 \mathrm{~mm}$ (158-174 mm), Chôshi, Chiba Pref., November 20-26, 1937. No. 8811, $112 \mathrm{~mm}(142 \mathrm{~mm})$, Kanaiwa, Ishikawa Pref., October 26 1942. No. 10186, $124 \mathrm{~mm}(165 \mathrm{~mm})$, Kasumi, Hy ôgo Pref., March 28, 1948. No. 10545, $145 \mathrm{~mm}(195 \mathrm{~mm})$, Maizuru, Kyôto Pref., December 1, 1948. No. $11295,139 \mathrm{~mm}$ (186 mm), Chôshi, April 4, 1949. No. 11496, $122 \mathrm{~mm}$ (160 mm), Wakasa Bay, April 28, 1949. No. 11534, $126 \mathrm{~mm}(170 \mathrm{~mm})$, Chôshi, May 3, 1949. Nos. 13057 and 13063, 104$142 \mathrm{~mm}(138-190 \mathrm{~mm})$, Wakasa Bay, May 1950. No. 14502, $126 \mathrm{~mm}(154 \mathrm{~mm})$, Maizuru, October 1950. Nos. $16467,16503,16509,16511-16524,16526-16535,16537-16547,16549$ and 16550, 91144 mm (123-194 mm), Kunda, Kyôto Pref., June 1, 1951. Nos. 18587-18589, 18592-18594 and 18598, 91-122 mm (121-161 mm), Mimase, Kôchi City, October 10, 1952. No. 20203, $121 \mathrm{~mm}$ $(161 \mathrm{~mm})$, Wakasa Bay, November 10, 1952. Nos. 19187-19188, 120-131 mm (165-174 mm), Owase, Mie Pref., November 11-15, 1952. Nos. 21175-21200, 111-143 mm (136-194 mm), Owase, November 5, 1953. Nos. 21313-21338, 112-147 mm (153-196 mm), Wakasa Bay, October 27, 1953. No. 24797, $67 \mathrm{~mm}(90 \mathrm{~mm})$, Owase, October-November, 1954.

Female. Nos. 781 and $786,112-113 \mathrm{~mm}(143-147 \mathrm{~mm})$, locality unknown. Nos. 1710, 17131716, 1718, 1720-1721, 1723-1724, 1726, 1728-1732, 1734 and 1738-1746, 88-125 mm (116-160 mm), Owase, January 4-8, 1936 . No. 5485, $84 \mathrm{~mm}(107 \mathrm{~mm})$, Chôshi, November 20-26, 1937. Nos. 88128814, 101-110 mm (130-145 mm), Kanaiwa, October 26, 1942. Nos. 9090-9091, 11290 and 11296, 92-138 mm (119-176 mm), Tsuiyama, Hyogo Pref., May 12, 1943. No. 11497, $139 \mathrm{~mm}(178 \mathrm{~mm})$, Wakasa Bay, April 28, 1949. Nos. 11535 and 11540, 123-133 mm (160-174 mm), Chôshi, May 3, 1949. No. 13049, 13050 and 13069, 116-139 mm (150-179 mm), Wakasa Bay, May 1950. No. 14501, $146 \mathrm{~mm}$ (187 mm), Maizuru, October 1950. Nos. 15131. and 15135, Owase, January 16-18, 1950. Nos. 16431-16435, 16437-16466, 16468-16477, 16481, 16485, 16487-16490, 16493-16499, 16501-16502, 16505-16507, 16525, 16536 and 16548, 88-128 mm (116-164 mm), Kunda, June 1, 1951. Nos. 21150, 21153-21155 and 21157-21168, 81-156 mm (103-201 mm), Owase, November 5, 1953. Nos. 2133921348, 21384 and 21389, 47.5-135 mm (61.5-169 mm), Miya, Aichi Pref., January 25, 1954.

Description.-D. IV to V, 8 to $10(9.0)$; A. 8 to $9(9.0)$; P. 18 to 21 (19.7); C. 10. Head 3.5 to $4.9(4.0)$ in standard length; body width 5.3 to 8.5 (6.6); body depth 7.3 to 11.3 (9.4); depth of caudal peduncle 15.3 to 25.5 (20.8). Snout length 2.1 to 3.7 (3.0) in head length; eye diameter 2.4 to 3.9 (3.1); interorbotal width 8.3 to 26.0 (16.5); 1 st dorsal ray 1.1 to $1.8(1.5) ; 2$ nd dorsal soft ray 1.2 to $1.9(1.6)$; 6th 
dorsal soft ray 1.4 to $2.5(1.9)$; 1 st anal ray 2.2 to $3.6(2.8)$; pectoral fin 0.8 to 1.3 (1.1); pelvic fin 0.8 to 1.3 (1.1).

Snout rather pointed, about as long as eye diameter. Preopercular spine shorter than eye, armed with three or four hooks above, and a short spinule directed forward at the base (Fig. 14D, $\mathrm{D}^{\prime}$ ). Caudal fin rounded, without filaments.

SEXUAL DIMORPHISM.--In the present species, there exists marked secondary sexual dimorphism in both the length and coloration of the first dorsal, caudal and anal fins (Table 10, figs. 14-15). In the male, the first dorsal spine is thickend and produced into a long flament, sometimes extending nearly to the base of the caudal fin when the fin is depressed, but others are slender, shorter and subequal in length to each other (Fig. 14A). The last dorsal soft ray is long, the tip extending as
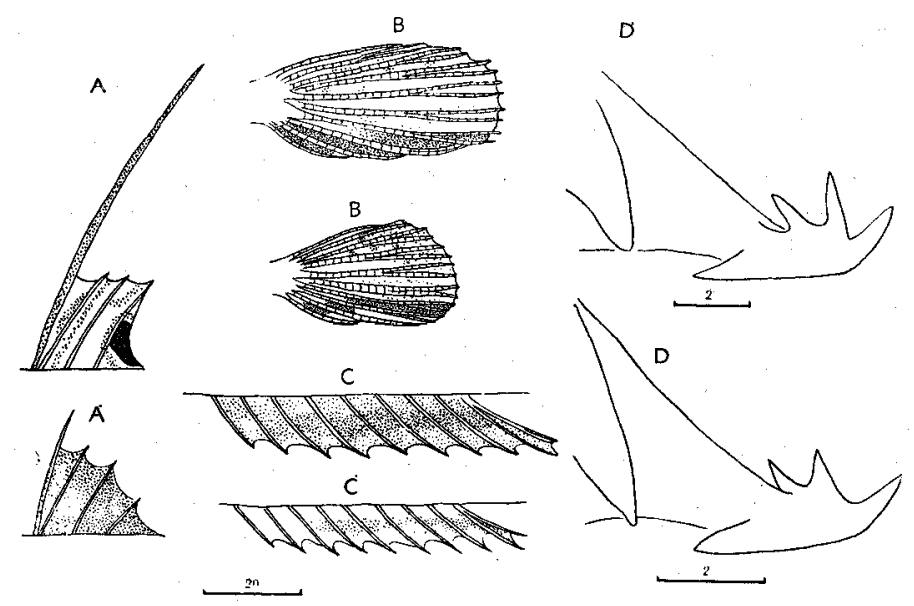

Fig. 14. First dorsal (A, $\left.A^{\prime}\right)$, caudal $\left(B, B^{\prime}\right)$, anal $\left(C, C^{\prime}\right)$, and preopercular spine $\left(\mathrm{D}, \mathrm{D}^{\prime}\right)$ in Callionymus lunatus TEMMINCK et Schlegel. A, B, C (No. 21317) and D (No. 21190), male; A', (No. 15131), $B^{\prime}, C^{\prime}$ (No. 21343) and $D^{\prime}$ (No. 21346), female. Drawn by OCHIAI and ARaga.

Table 10. Sexual dimorphism found in some proportional measurements against head length in Callionymus lunatus TEMmINCK et SCHLEgel.

\begin{tabular}{l|c|c|c|c}
\hline \multirow{2}{*}{ Sex } & \multicolumn{2}{|c|}{ Male } & \multicolumn{2}{c}{ Female } \\
\cline { 2 - 5 } Items & Range & Average & Range & Average \\
\hline 1st dorsal spine & $0.4-0.8$ & 0.6 & $1.3-2.3$ & 1.9 \\
2nd dorsal spine & $1.3-2.6$ & 1.9 & $1.4-3.3$ & 2.6 \\
3rd dorsal spine & $1.5-2.1$ & 1.7 & $1.8-4.2$ & 2.8 \\
4th dorsal spine & $1.5-3.1$ & 1.9 & $3.2-6.3$ & 5.0 \\
Last dorsal ray & $0.8-1.2$ & 1.0 & $1.0-2.1$ & 1.5 \\
Caudal fin & $0.7-1.1$ & 0.8 & $0.6-1.0$ & 0.9 \\
\hline
\end{tabular}




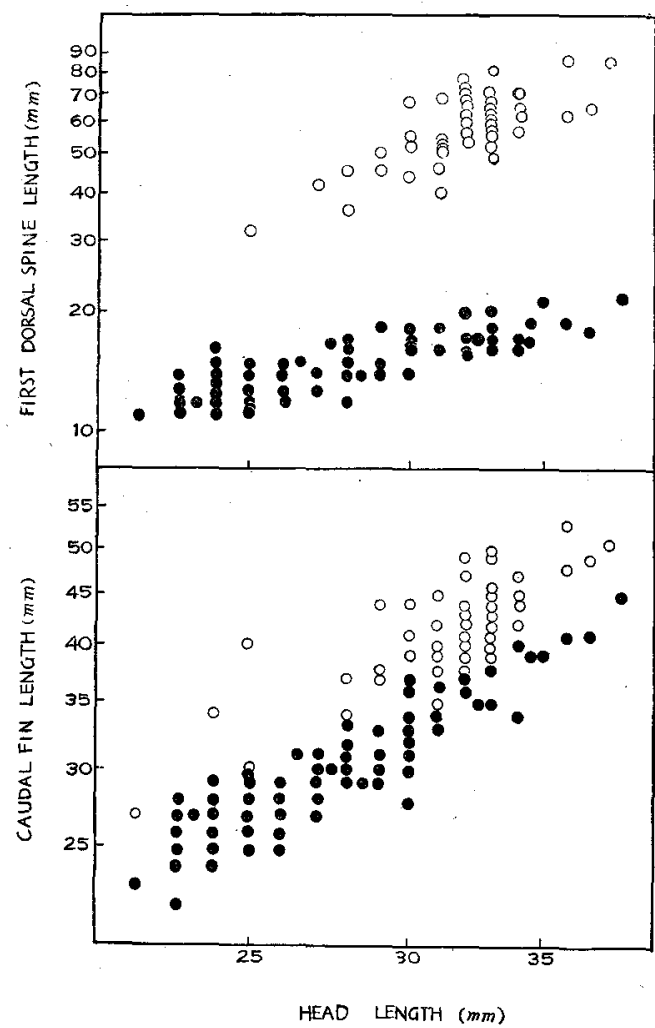

Fig. 15. Dimentions of first dorsal spine and caudal fin in Callionymus lunatus TEMMINCK et SCHLEGEL in relation to the head length. $O$, male. female. far beyond the base of the caudal fin when the fin is depressed. The caudal fin is rounded and rather longer than the head length (Fig. 14B). The last anal soft ray is also long, and reaches to the base of caudal fin. The first dorsal fin is pale, marked with irregular dark streaks, and ocellated ${ }^{1)}$ with black on the membrane behind the last dorsal spine (Fig. 14A). The lower edge of the caudal fin is uniformly black (Fig. 14B). The anal fin is dark, and darker along the median axis of the fin (Fig. 14C).

In the female, the dorsal spines are short and never reaches to the origin of the second dorsal fin when the spines are depressed. The last dorsal and anal soft rays are short, scarcely extend to the base of the caudal fin. The caudal fin is obliquely truncated and the longest lower ray is nearly as long as the head (Fig. 14B). The first dorsal fin is black, but the basal region is somewhat light (Fig. 14A'). The lower part of the caudal fin is dark, edged with white

(Fig. 14B'). The anal fin is pale, with a dark band along the median axis of the fin (Fig. 14C').

REMARKS.-By KURODA (1952:174, fig. 6), the present species is splitted into two forms (form. lunatus and form. usuiro) based mainly upon the length of the first dorsal spine and the general coloration of the body. Of these two forms, C. lunatus form. usuiro is characterized by having a body much lighter and the first dorsal spine in the male much longer, extending nearly as far beyond the base of the caudal fin. Already, Schmid T (1931 b : 142-143) pointed out that in some specimens of this species taken from Japan, the first dorsal spine extends to the base of the last dorsal soft ray when the spine is depressed backward. It can hardly be justifiable to accept

1) Occasionally, the ocellus is more or less broken up (SNYDER, 1912:446). In one of our specimen (No. 23578) taken at Wakasa Bay, the fin is furnished with two blackish ocelli, the one placed on the general place and the other laid between the third and fourth spines. But the latter is more or less lighter than the former. 
KURODA's opinion, inasmuch as the first dorsal spine in the male strikingly increases in length with the growth of the fish, ${ }^{1)}$ and there can be found no significant correla. tion between the length of the spine and the general coloration of the body.

The description of this species given by JORDAN and FowLER (1903:945-950) contains some erroneus points in the coloration of the anal and caudal fins of the male. The characteristics given by them on these fins are indeed those of the female. According to their descriptions the illustration of this species appears to be based upon a male. But it should be mentioned that their illustration shows clearly the female features in both the form and coloration of the first and second dorsal, caudal and anal fins.

\section{Callionymus huguenii BLEEKER}

\section{Nagasaki-numeri}

Callionymus huguenii.-GÜNTHER, 1861:145-146; JORDAN et FOWLER, 1903:995-956; JORDAN, TANAKA et SNYDER, 1913:377.

? Callionymus huguenii.-IsHTKAwA et MatsUBARA, $1897: 37$.

? Callionymus higuenii--SCHMIDT, $1931 \mathrm{~b}: 144$.

The present species was described by BLEeker from a single specimen, which appears to be male. No specimens have come under our examination, but according to the original description the species is characterized in the following points: dorsal and anal soft rays each 10 ; preopercular spine not longer than eye diameter, terminating in three large curved hooks; first dorsal with filiform spines, the first being the longest, much longer than head; caudal fin pointed, as long as head; first dorsal plain; anal edged with black.

It is doubtful whether IsHIKawa and MatsuUra's (1897:37) C. huguenii taken from Hakodate, Prov. Hokkaido, really belongs to this species or not. Also, we doubt the conclusion that a young female found at Misaki and described as C. higuenii by Schmid (1931 b:144) is identical to this species.

\section{Callionymus beniteguri JORDAN et SNYDER \\ Tobi-numeri}

(Figs. 16-17)

Callionymus beniteguri.-JORDAN et SNYDER, 1900:370-371, pl. 42; JORDAN et FOWLER, 1902: 956-957; FrANZ, 1910:84; SNYDER, $1912: 447$; JORDAN, TANAKA et SNYDER, 1913:375; JoRdan et HubBS, $1925: 317$; SchMidT, $1931: 143$; FoWLER, $1941: 22$; HiKITA, $1951: 311$; HONMA, 1952 : 226 ; BÖHLKE, 1953: 103.

1) Holotype of Callionymus lunatus form. usuiro ( $\delta$ ) is $146 \mathrm{~mm}$ in standard length. So far as our observations go, the first dorsal spine greatly increases in length (about $75 \mathrm{~mm}$ ) when the male attains that size. 
Callionymus ornatipinnis.-REGAN, $1905: 24$, pl. 3; JORDAN, TANAKA et SNYDER, $1913: 375$.

? Callionymus kanekonis.-TANAKA, $1917: 7-12$; TANAKA, $1931: 40$.

MAterial examined.-Male. Nos. 4692 and 6495-6497, 104-115 mm (142-153 mm), Owase, Mie Pref., December 1936. 'No. 9736, $131 \mathrm{~mm}$ (166 mm), Shiogama, Miyagi Pref., November 1, 1944. No. 10304, $130 \mathrm{~mm}(170 \mathrm{~mm})$, Funakawa, Akita Pref., June 1948. No. 11541, $142 \mathrm{~mm}$ (198 mm), Chôshi, Chiba Pref., May 3, 1949. Nos. 16811-16814, 82-120 mm (108-155mm), Ôsaka, October 1950. No. 17399, $66 \mathrm{~mm}(90 \mathrm{~mm})$, Owase, January 3-7, 1952. Nos. 20683 and 20684, 100-1i3 mm (127-148 mm), Miya, Aichi Pref., April 10, 1953. No. 23059, $121 \mathrm{~mm}$ (170 mm), Maizuru, August 26, 1954. Nos. (Hokkaido Univ. Fish Coll.) 5482-5488, 98-153 mm (129-207 mm), Oshoro, Prov. Hokkaido.

Female. No. 23060, $102 \mathrm{~mm}$ (140 mm), Maizuru, August 26, 1954. No. (Hokkaido Univ., Fish Coll.) 5489, $82 \mathrm{~mm}(107 \mathrm{~mm})$, Muroran, Prov., Hokkaido.

Description.-D. IV, 8 to $9(9.0)$; A. 9 ; P. 18 to $22(19.8)$; C. 10 . Head 3.6 to $4.2(4.0)$ in standard length; body width 5.9 to 7.4 (6.2); body depth 8.2 to 12.3 (10.0) ; depth of caudal peduncle 17.3 to 23.5 (20.4). Snout length 2.1 to 2.7 (2.5) in head length; eye diameter 2.2 to 4.5 (3.7); interorbital width 8.9 to 22.0 (125); 1st dorsal soft ray 1.6 to $2.0(1.7) ; 2$ d dorsal soft ray 1.4 to 2.1 (1.8); 6th dorsal soft ray 1.4 to 2.1 (1.8); 1st anal ray 2.7 to 3.7 (3.0); pectoral fin 1.2 to 2.0 (1.4) ; pelvic fin 0.8 to $1.4(1.0)$; caudal fin 0.6 to $1.0(0.8)$.

Snout broad, pointed and much longer than eye. Interorbital space rather wide and strongly concave, about $1 / 3$ as wide as eye diameter. Preopercular spine very short, about half as long as eye diameter, with three or four hooks above, and a spinule directed forward at base (Fig. 17D, $D^{\prime}$ ). Last dorsal and anal soft rays reach to or extending beyond base of caudal fin.

Sexual dimorphism.--Remarkable sexual dimorphism exists in the length and coloration of the dorsal caudal and anal fins (Table 11, figs. 16-17). This divergence becomes conspicuous when the fish reaches to at least $82 \mathrm{~mm}$ in standard length. In the male, the anterior two dorsal spines are long, slender, ending in filaments and

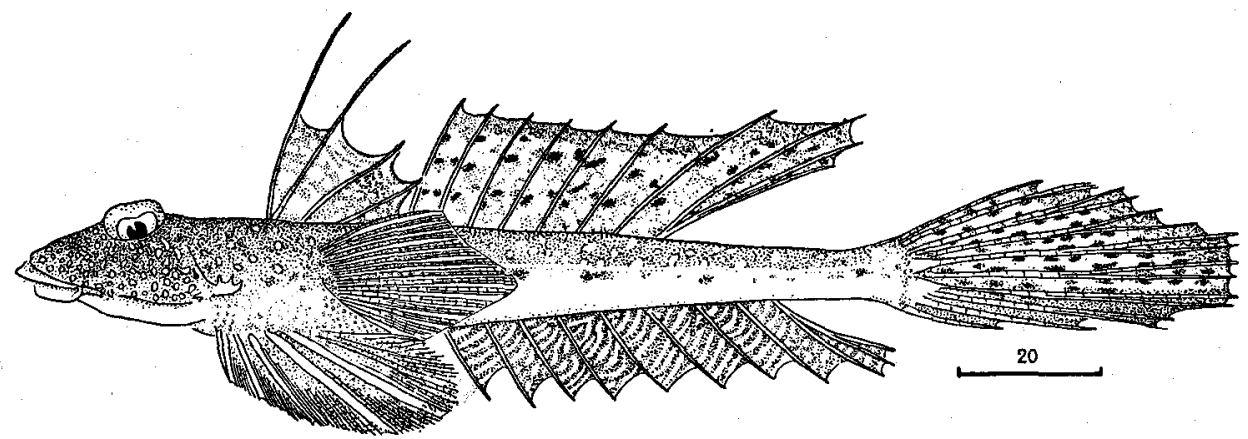

Fig. 16. Lateral view of Callionymus beniteguri JORDAN et SNYDER (male): No. 23059, $121 \mathrm{~mm}$ in standard length. Drawn by OcHIAl. 


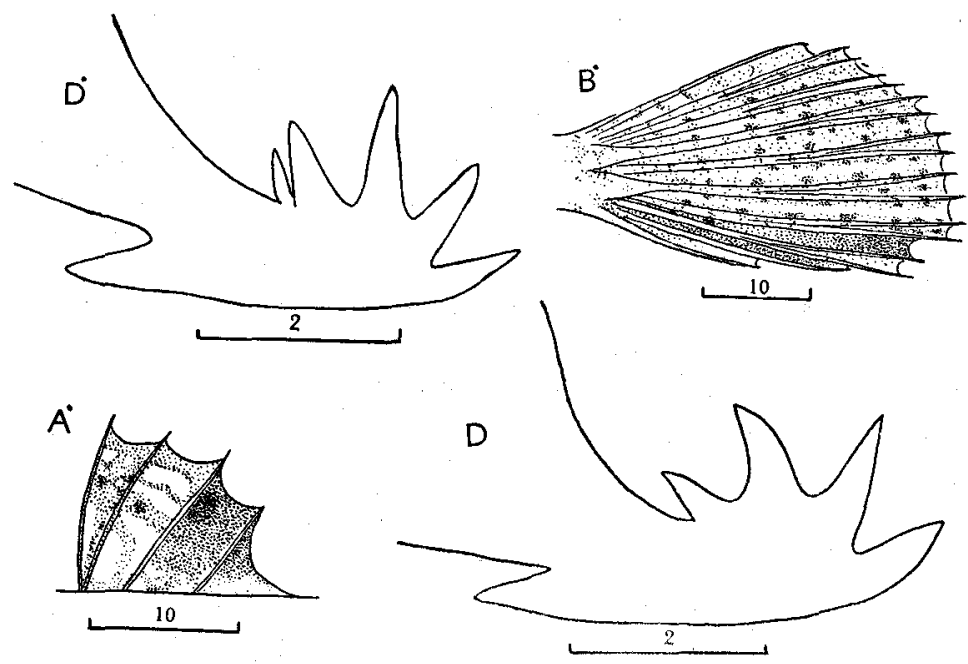

Fig. 17. First dorsal $\left(A^{\prime}\right)$, caudal $\left(B^{\prime}\right)$ and preopercular spine (D, $\left.D^{\prime}\right)$ in Callionymus beniteguri JORDAN et SNYDER. D (No. 23059), male; $\mathrm{A}^{\prime}, \mathrm{B}^{\prime}$, and $\mathrm{D}^{\prime}$ (No. 23060), female. Drawn by OchtaI.

Table 11. Sexual dimorphism in some proportional measurements against head length in Callionymus beniteguri JORDAN et SNYDER.

\begin{tabular}{|c|c|c|c|}
\hline \multirow[b]{2}{*}{ Items } & \multicolumn{2}{|c|}{ Male } & Female \\
\hline & Range & Average & Range \\
\hline 1st dorsal spine & $1.0-2.0$ & 1.4 & $2.2-2.5$ \\
\hline 2nd dorsàl spine & $0.8-1.9$ & 1.4 & 2.2 \\
\hline 3rd dorsal spine & $1.5-2.5$ & 1.9 & $2.5-3.2$ \\
\hline 4th dorsal spine & $2.5-4.7$ & 3.2 & $3.9-4.4$ \\
\hline Last dorsal ray & $0.9-1.4$ & 1.1 & $1.4-1.5$ \\
\hline Caudal fin & $0.6-1.0$ & 0.8 & $0.7-0.9$ \\
\hline
\end{tabular}

sometimes extend to the base of the fourth dorsal soft ray when the fin is depressed, but the two posterior spines are much shorter. The last dorsal soft ray is greatly elongated, and the tip extends as far beyond the base of the caudal fin. The three median caudal rays are longer than the others. The anal fin is rather low; and the last ray extends a little beyond the base of the caudal fin. The first dorsal fin is grey, speckled with white spots and streaks, and membrane between the third and fourth spines is edged with black spots. The second dorsal is grey, furnished with two or three longitudinal rows of conspicuous blackish spots which are about as long as the interotbital width. The anal fin is either uniformly pale, or black dyed with numerous oblique wavy light streaks.

In the female, the dorsal spines are all short and never filamentous (Fig. 17 $\mathrm{A}^{\prime}$ ), the last dorsal and anal soft rays are rather short, but extend to the base of the 
caudal fin. The caudal fin is rather short and rounded (Fig. 17B'). The first dorsal fin is provided with numerous dusky lines and white blotches on the membrane of the first three spines, but the rest of the fin is rather black (Fig. 17 $\mathrm{A}^{\prime}$ ). The blackish spots placed on the second dorsal are shorter than the interorbital width. The anal fin is uniformly pale.

REMARKs.-Variety of this species found in the coloration of the body has already been pointed out by JORDAN and Fowler (1903:957). Two types may be distinguished in the coloration of the anal fin as aforementioned. Our male specimens characterized by the striped anal fin agree well with the female paratypes of the present species. While, the males with uniformly pale anal fins accord with the holotype of Callionymus ornatipinnis REGAN in every feature.

Callionymus kanekonis TANAKA, which is thought to be a synonym of this species, is allied well with the present species in length of the first dorsal spine, the preopercular spine, the last dorsal ray, and the coloration of the body and fins, but the head is slightly larger ( $31 / 3$ in standard length) and the snout is more or less shorter (31/3 in head length).

\section{Callionymus valenciennesi TEMMINCK et SCHLEGEL}

Hatatate-damashi (new Japanese name)

Callionymus valenciennesi.-TEMmINCK et SChlegel, 1845:153, pl. 73, fig. 3; Brevoort, 1856: 271 ; Jordan et HubBs, $1925: 317-318$ (in part); BoESEMAN, $1947: 131-133$.

No specimens have come under our examination, but according to the original description and figure, the characteristics of this species (male) are summarized as follows: dorsal spines all filamentous, nearly twice as high as the membrane, first and second spines greatly produced, somewhat longer than head; soft dorsal and anal rather short, their last rays not extend to base of caudal fin; caudal not filamentous; first dorsal pale with a few large dark specks; anal pale edged with black.

In his revision of the Japanese fishes collected by BURGER and VON SIEBOLD, BOESEMAN (1947: 131-133) annotated that a specimen (No. 2078) must be the fish which represented as a male of $C$. valenciennesi of TEMMINCK et SchlEgEL, but other specimens (Nos. $2079 \mathrm{a}, \mathrm{b}$ and 1011) may belong to either C. beniteguri JoRDAN et SNYDER or C. punctatus LANGSDORFF.

\section{Callionymus virgis JORDAN et FOWLER}

Horo-numeri

(Figs. 18-19)

Callionymus virgis.-JORDAN et FOWLER, 1903:957-958, fig. 9; Franz, 1910:85; JoRDAN, TANAKA et SNYDER, $1913: 376$, fig. 336 ; KAMOHARA, 1938:65; KURODA, $1951: 386$; KAMOHARA, $1952: 89$; KURODA, $1952: 174$; BÖHL KE, $1953: 104$; KURODA, $1954 ; 160-161$. 
Material Examined.-Male. Nos. 11297-11299, 48-55 mm (60.5-68 mm), Tsuiyama, Hyôgo Pref., June 4, 1949. Nos. 13063, 13068, 13070-13073 and 13075, 52-60 mm (65-76 mm), Wakasa Bay, May 1950. No. 15295, $57 \mathrm{~mm}$ (73 mm), Owase, Mie Pref., January 15-20, 1950 . Nos. 1655816560, 45-51 mm (55-67 mm), Kunda, Kyôto Pref., June 1, 1951. Nos. 18596 and 18597, Mimase, Kôchi City, October 10, 1952. No. 18738, $83 \mathrm{~mm}(105 \mathrm{~mm})$, Urado, Kôchi City, October 15, 1952. Nos. 21896-21908 and 21910-21936, 52-79.5 mm $(67-104 \mathrm{~mm})$, Mimase, April 10-20, 1954. Nos. 24818-24821, 24823-24824 and 24825-24845, 40-71 mm (53-92 mm), Owase October 25, 1954.

Female. Nos. 11291, 11293 and 11294, 41-48.5 mm (51-62 mm), Tsuiyama, April 1949. Nos. 13074 and 13076, 47.5-53 mm (62.5-69 mm), Wakasa Bay, May 1950. Nos. 21869, 21871 and 21872, 48.5-50.5 mm (61-65 mm), Mimase, April 10-20, 1954.

DESCRIPTION.-D. IV, 8 to $10(9.0)$; A. 8 to $10(9.0)$; P. 17 to $21(19.0)$; C. 10. Head 3.7 to 4.9 (4.3) in standard length; body width 4.4 to 7.3 (6.2); body depth 7.9 to 16.6 (10.5); depth of caudal peduncle 16.0 to 23.3 (19.9). Snout length 2.6 to 4.0 (3.3) in head length; eye diameter 2.0 to 3.7 (3.0); interorbital width 9.5 to 19.0 (14.7); 1st dorsal soft ray 1.0 to $1.4(1.2)$; 2 nd dorsal soft ray 0.9 to 1.9 (1.3); 1st anal soft ray 1.9 to $3.7(2.7)$; pectoral fin 0.8 to $1.3(1.1)$; pelvic fin 0.6 to 1.3 (1.0); caudal fin 0.7 to $1.1(0.8)$.

Snout pointed and more or less shorter than eye diameter. Preopercular spine rather short, nearly half as long as eye diameter, armed with three or four conspicuous hooks above, the hindmost one turning upward and backward, but the others upward and forward; a spinule directed forward at the base (Fig. 18D, D'). Caudal fin not elongate. Anal pale, with faint dark streaks on the membrane.

SEXUAL DIMORPHISM.--This species displays most remarkable sexual dimorphism in this group (Table 12, fig. 18). The dimorphism becomes significant when the fish attains at least $40 \mathrm{~mm}$ in standard length. In the male, the dorsal spines are all very long, filamentous, and subequal in length. The membrane of the first dorsal fin is very high and joined to the first dorsal soft ray (Fig. 18A). The last dorsal soft ray extends as far as the base of the caudal fin, but the last anal soft ray scarcely reaching it when the fin is depressed. The first dorsal fin is grey, furnished with some irregular vertical light streaks; the base and the first spine are black (Fig. 18A).

Table 12. Sexual dimorphism found in some proportional measurements against head length in Callionymus virgis JORDAN et FOWLER.

\begin{tabular}{c|c|c|c|c}
\hline \multirow{2}{*}{ Sex } & \multicolumn{2}{|c|}{ Male } & \multicolumn{2}{c}{ Female } \\
\cline { 2 - 5 } Items & Range & Average & Range & Average \\
\hline 1st dorsal spine & $0.3-0.7$ & 0.4 & $1.5-1.9$ & 1.7 \\
2nd dorsal spine & $0.3-0.6$ & 0.4 & $1.7-2.2$ & 1.8 \\
3rd dorsal spine & $0.3-0.5$ & 0.3 & $1.8-2.8$ & 2.2 \\
4th dorsal spine & $0.3-0.6$ & 0.4 & $2.5-3.5$ & 2.9 \\
6th dorsal ray & $1.2-2.1$ & 1.5 & $1.9-2.7$ & 2.1 \\
Last dorsal ray & $0.7-1.3$ & 1.0 & $1.5-1.7$ & 1.7 \\
\hline
\end{tabular}




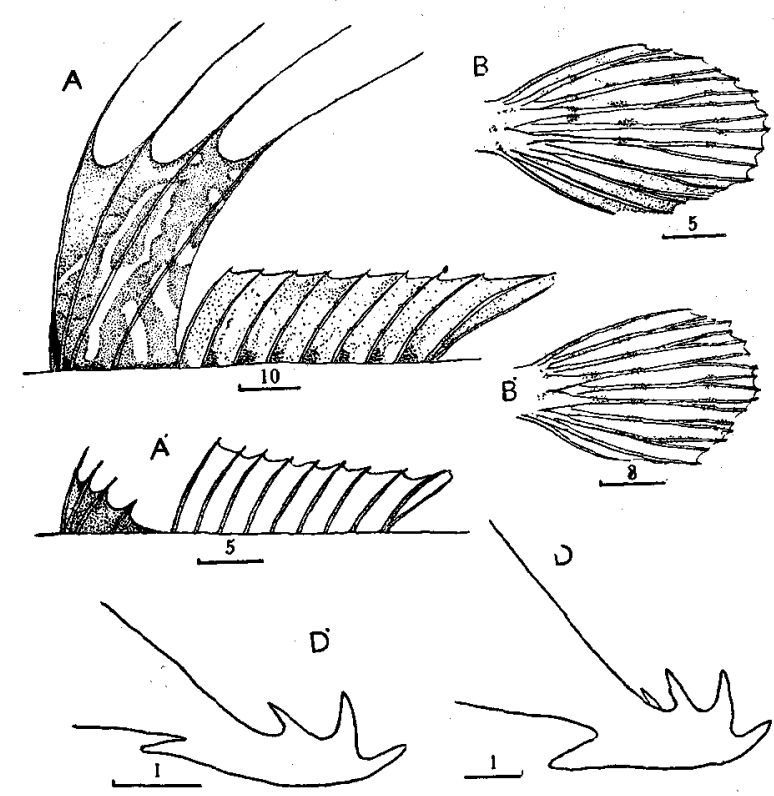

Fig. 18. First dorsal (A, $\left.A^{\prime}\right)$, caudal $\left(B, B^{\prime}\right)$ and preopercular spine $\left(\mathrm{D}, \mathrm{D}^{\prime}\right)$ in Callionymus virgis JoRDAN et Fowler. A, B (No. 21902) and D (No. 21931), male; $A^{\prime}, B^{\prime}$ (No. 21972) and $D^{\prime}$ (No. 21871), female. Drawn by ARAGA.

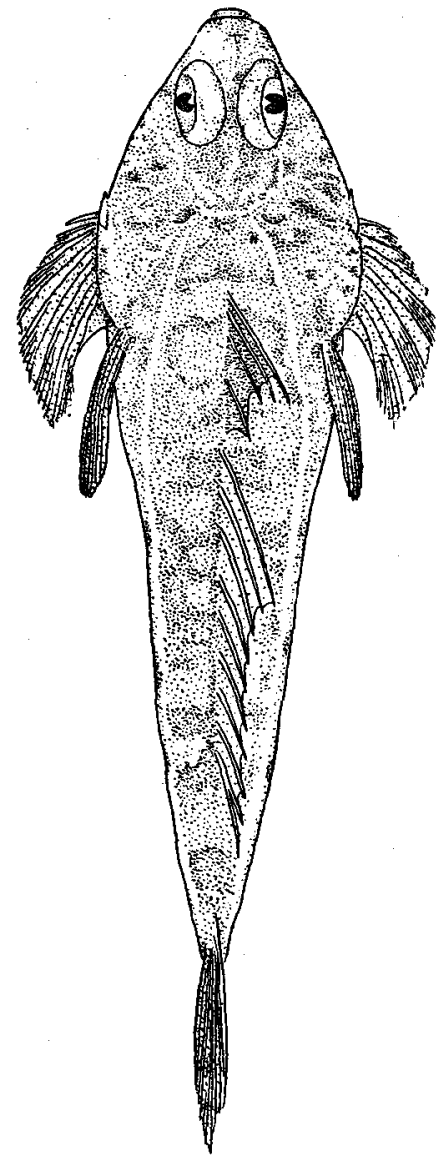

10

Fig. 19. Upper view of Callionymus virgis JORDAN et FOWLER (female): No. $21869,48.5 \mathrm{~mm}$ in standard length. Drawn by ARAga and OchIAI.

The second dorsal fin is pale and ornamented with blackish blotches at the base of the caudal.

In the female, the dorsal spines are all short, and the membrane is neither high nor joined to the second dorsal fin (Fig. 18A, $A^{\prime}$ ). The last dorsal and anal soft rays are not extending to the base of the caudal fin. The first dorsal fin is uniformly brownish black. The second dorsal fin is almost pale and without any markings (Fig. 18A').

REMARKs. - In our regions, the male of the present species is rather common 
together with Callionymus flagris JORDAN et FOwLER, but the female has never been found for a long time until some specimens were reported from Prov. Izu by KurodA (1954:160-161).

\section{Callionymus kitaharai ${ }^{13}$ JORDAN et SEALE}

Kuro-numeri

Callionymus kitaharae.-JORDAN et SEALE, $1906: 148$, fig. 6 ; JORDAN, TANAKA et SNYDER, 1913: 375, fig. 334 ; MORI, 1952 : 132 ; BÖHLKE, $1953: 103$.

No specimens have come under our examination, but from the original description and figure, the present species is characterized in the following points: eye (2.5 in head length) larger than snout ( 3.0 in head length); preopercular spine distinctly shorter than eye, with four hooks on the upper edge, and the basal spinule directed forward; dorsal spines short; the first the longest, scarcely longer than eye; second dorsal becomes gradually shorter posteriorly; last dorsal and anal soft rays not extend to base of caudal fin; a dark blotch crescentic in shape present on spinous dorsal between second and third spines, and a similar but larger one between third and fourth spines.

This fish accords well with the female of Callionymus virgis JORDAN et FOWLER in numerous characteristics except for the coloration of the first dorsal. In the latter the fin is uniformly black.

\section{LITERATURE CITED}

Alcock, A. W. 1899. A descriptive catalogue of the Indian deep-sea fishes in the Indian Museum. Being a revised account of the deep-sea fishes collected by the royal Indian marine survey ship "Investigator", iii +211 pp., 43 pls., Culcutta.

BARNARD, K. H. 1927. A monograph of the marine fishes of South Africa, part 2. Ann. South African Museum, 21, pp. 419-1065, figs. 19-32, p]s. 18-37.

BEAUfORT, L. F. and CHAPMAN, W. M. 1951. The fishes of the Indo-Australian archipelago, ix. Percomorphi (concluded), Blennoidea. $x i+484$ pp., 89 figs. Leiden.

Blegvad, H. 1944. Fishes of the Iranian Gulf. Danish Scientific Investigations in Iran, Part 3 , pp. 1-135, pls. 1-2.

BOESEMAN, M. 1947. Revision of the fishes collected by BURGER and von SIEBOLD in Japan. Zoologische Mededeelingen (Leiden), 28, pp. 1-242, plus. 1-5.

BÖHLKE, J. 1953. A catalogue of the type specimens of recent fishes in the Natural History Museum of Stanford University, Stanford Ichthyological Bull., 5, pp. 1-168.

BREvoORT, J. C. 1856. Notes on some figures of Japanese fish takes from recent specimens by the artists of the U.S. Japan expedition. Narrativ Commander M. C. PERRY's Expedition to Japan, 2, pp. 255-288, col. pls. 3-12.

Chen, K. 1951. Monograph of fishes of Formosa. Quarterly Jour. Taiwan Bunk, 4(3), pp. 110163. [In Chinese.]

DAY, F. 1889. The fauna of British India, including Ceylon and Burma, Fishes. 2, 509 pp., 177 figs., London.

1) The specific name kitaharae is emended to kitaharai, in conformance with the new obligatory rule on the formation of patronymics. 
Evermann, B. W. and Seat, A. 1907. Fishes of the Philippine Islands. Bull. Bur. Fisher., 26 (607), 1906, pp. 49-110, figs. 1-22.

Fujita, T. and WakIYA, Y. 1915. List of fishes found in province Kii. Suisan-gakkaiho, 1 (1), pp. 25-37. [In Japanese.]

Fowler, H. W. 1928. The fishes of Oceania. Mem. Bernice P. Bishop Mus., 10, pp. i-iii, $1-540$, figs. $1-82$, pls. $1-49$.

1936. The marine fishes of West Africa based on the collection of the American Museum Congo expedition, 1909-1915. Bull. American Mus. Nat. Hist., 70 (2), pp. 607-1493, figs. 276-567.

1941. New fishes of family Callionymidae, mostly Philippine, obtained by the United States Bureau of Fisheries steamer "Albatross.". Proc. U.S. Nat. Mus., 90 (3106), pp. 1-31, figs. 1-16.

Franz, V. 1910. Die japanische Knochenfische der Sammlungen Haberer und Doflein. In Beiträge zur Naturgeschichte Ostasiens. Abhandlungen der math-phys. Klasse der K. Bayer Akad. der Wiss., 4, Suppl.-Bd, 1, pp. 1-135, figs. 1-7, pls. 1-11.

GILBERT, C. H. 1905. The aquatic resources of the Hawaiian Islands. Section II.-The deepsea fishes. Bull. U.S. Fish Comm. for 1903, 23 (2), pp. 1-xi, 575-713, figs. 230-276, pls. 66-101.

Goode, G. B., and BEAN, T. H. 1895. Oceanic ichthyology. xxxv +553 pp., 123 pls. U.S. Nat. Mus., Spec. Bull. Washington.

Günther, A. 1861. Catalogue of the fishes in British Museum, 3, xxv+586 pp., London. 1876-81. Andrew Garretr's Fische der Südsee II. Jour. Mus., Godeffroy, 4, pp. i-ii, 129-256, pls. 84-140.

1880. Report on the shore fishes procured during the Voyage of H. M. S. "Challenger" in the years 1873-76. Report on the Scientific Results of the Voyage of H. M. S. "Challenger" etc., Zoology, 1 (6), 82 pp., 32 pls. London.

HikiTA, T. 1951. Fishes of Volcano Bay in Hokkaido. Jap. Jour. Ichth. 1 (5), 306-313.

Honma, H. 1952. A list of the fishes collected in the province of Echigo, including Sado Island. Jap. Joun. Ichth. $2(4,5)$, pp. 220-229. [In Japanese.]

Ishikawa, C. and MATsuURA, K. 1897. Preliminary catalogue of fishes including Dipnoi, Cyclostomi and Cephalochorda in the collection of the Natural History Department, Imperial Museum. 64 pp. Tokyo Imperial Museum. [In Japanese].

IzUKA, A. and MAtsuUrA, K. 1920. Catalogue of the zoological specimens exhibited in the Natural History Department, Tokyo Imperial Museum (Vertebrata). 192 pp., 5 pls. Tokyo Imperial Museum. [In Japanese.]

Jordan, D. S. 1923. A classification of fishes, including families and genera as far as known. Stanford Univ. Pub., Univ. Ser., Biol. Sci., 3 (2), pp. 79-243.

and Evermann, B. W. 1898. The fishes of North and Middle America. A descriptiv catalogue of the species of fish-like vertebrates found in the waters of North America, north of the isthmus of Panama (Parts 1-4). Bull. U.S. Nat. Mus., (47), 3313 pp., 392 pls., Washington.

1905. The aquatic resources of the Hawaian Islands. part 1.-

The shore fishes. Bull. U.S. Fish Comm., 23 (1) for 1903, pp. i-xxviii, 1-574, figs. 1-229, pl. 1-65, col. pl. 1-73.

and Fowler, H. W. 1903. A review of the dragonets (Callionymidae) and related

fishes of the waters of Japan. Proc. U.S. Nat. Mus., 25 (1305), pp. 939-959, figs. 1-9.

and HuBBs, C. L. 1925. Record of fishes obtained by David Starr JorDan in

Japan, 1922. Mem. Carnegie Mus., 10 (2), 93-346, fig. 1, pl. 5-12.

and JORDAN, E. K. 1922. A list of the fishes of Hawaii, with notes and descrip-

tions of new species. Mem. Carnegie Mus., 10 (1), pp. 1-92, figs. 1-7, pls. 1-4.

and MExz, C. W. 1913. A catalogue of the fishes known from the waters of

Korea, Mem. Carnegie Mus., 6 (2), pp. 1-65, figs. 1-67, pls. 1-10. 
Jordan, D. S. and SEALE, A. 1906 a. Descriptions of six new species of fishes from Japan. Proc. U.S. Nat. Mus., 30 (1445), pp. 143-148.

$1906 \mathrm{~b}$. The fishes of Samoa. Description of the species found in the archipelago, with a provisional check list of the fishes of Oceania. Bull. Bur. Fisher., 25,1905 , pp. $173-455$, figs. 1-111, pls. $33-53$.

and SNyDER, J. O. 1900. A list of fishes collected in Japan by Keinosuke OTAKI, and by the United States steamer "Albatross", with description of fourteen new species. Proc. U.S. Nat. Mus., 23 (1213), pp. 335-380, pls. 9-20.

and STARKS, E. C. 1904. List of fishes dredged by the steamer "Albatross" off the coast of Japan in the summer of 1900 , with descriptions of new species and review of the Japanese Macrouridae, Bull. U.S. Fish Comm. for 1902, 22, pp. 577-628, 52 figs., pls. 1-8. 1905. On a collection of fishes made in Korea, by Pierre Louis

Jouy, with descriptions of new species. Proc. U. S. Nat. Mus., 28 (1391), pp. 193-212, figs. $1-11$.

TANAKA, S. and SNYDER, J. O. 1913. A catalogue of the fishes of Japan. Jour. Coll. Sci., Imp. Univ. Tokyo, 33 (1), pp. 1-497, figs. 1-396.

and Thompson, W. F. 1914. Record of the fishes obtained in Japan in 1911. Mem. Carnegie Mus., 6(4), pp. 205-313, figs. 1-87, pls. 24-42.

Katayama, M. 1940. List of fishes found in Toyama Bay. Toyama Hakubutsu Gakkai Shi, (3), pp. 1-28. [In Japanese.]

_ _ 1950. List of fishes dredged by trawlers from East China and Yellow Sea, 12 pp. [In Japanese, Mimeographed.]

Kamomara, T. 1936 a. Commercial fishes dredged by motor trawlers in prov. Tosa. Suisan Kenkyu Shi, $31(3)$, pp. 1-10. [In Japanese.]

446-448, figs. 1-2.

- 1938. On the offshore bottom-fishes of prov. Tosa, Shikoku, Japan. 86, pp. 43 figs., Maruzen Co., Tokyo.

1951. Notes on some rare fishes from prov. Tosa, Japan. Kôchi Univ. Nat. Sci. (1), pp. 1-8, pls. 1-11.

1952. Revised descriptions of the off shore bottom-fishes of prov. Tosa, Shikoku, Japan. Rep. Kôchi Univ. Nat. Sci., (3), pp. 1-122, figs. 1-100.

Korke, M. 1936. List of aquatic animals of Fukui Pref. (Vertebrata), 15 pp. [In Japanese, Mimeographed.]

KURODA, N. 1931. List of the fishes found in the waters near Shizuura, prov. Suruga. Ameoba, $3(1-2)$, pp. 85-127, 11 figs. [In Japanese.]

1951. A nominal list with distribution of the fishes of Suruga Bay, inclusive of the freshwater species found near the coast. Jap. Jour. Ichth., 1 (6), pp. 376-394. [In Japanese.]

1952. Additions to the fishes of Suruga Bay (10), with corrections. Zool. Mag. $61(6)$, pp. 169-177, figs. 4-9. [In Japanese.]

1954. On the life colours of some fishes,-III. Jap. Jour. Ichth. 3 (3-5), pp. 153-161, figs. 1-4. [In Japanese.]

MAKo, H. 1949. List of the fishes obtained from East China Sea and Yellow Sea, by the morter trawlers, (1). Tôkai, Kôkai Sokouo Shigen Chôsa (1), pp. 125-136. [In Japanese.]

MCCulloch; A. R. 1926. Report on some fishes obtained by the F.I.S. "Endeavour" on the coasts of Queensland, New South Wales, Victoria, Tasmania, South and south-western Australia. Biological Results of the Fishing Experiments carried on by the F. I. S. "Endeavour" 1909-14. (H. C. Dannevig, Commonwealth Director of fisheries), 5 (4), pp. 157-216, pls, xliii-lvi, figs. 1-4.

1929. A check-list of the fishes recorded from Australia. Mem. Australian Mus., 5 (3), pp. 329-436. 
MCCulfoch, A. R. 1934. The fishes and fish-like animals of New South Wales. Third edition with supplement by Gilbert P. WHITLEY, 104 pp., 43 pls. Royal Zoological Society of New South Wales.

Mori, T. 1928, A catalogue of the fishes of Korea. Jour. Pan-Pacific Res. Inst., 3 (3), pp. 3-8. - 1952. Check list of the fishes of Korea. Mem. Hyôgo Univ. Agri., 1 (3), pp. 1-228, 1 map.

- and UCHIDA, K. 1934. A revised catalogue of the fishes of Korea. Jour. Chôsen Nat. Hist. Soc., (19), pp. 1-23.

NAkamura, S. 1934. List of the fishes found in Toyama Pref. $27+2 \mathrm{pp}$. [In Japanese, Mimeographed.]

Norman, J. R. 1937. Fishes. B. A. N.Z. Antartic Research Expedition 1929-1931. Series B (Zoology and Botany), 1 (2), pp. 51-88, figs. 1-11.

Nyström, E. 1887. Ređogörelse för den Japaniska Fisksamligen I. Upsala Universitates Zoologiska Museum. Bihang till K. Svenska Vet. Akad. Handlingar. 13-4 (4), pp. 1-54.

OKADA, Y. and MAtsubarA, K. 1938. Keys to the fishes and fish-like animals of Japan, including Kuril Islands, Southern Sakhalin, Bonin Islands, Ryûkyu Islands, Korea and Formosa. xi+584 pp., 113 pls. Sanseido Co., Tokyo. [In Japanese.]

REGAN, C. T. 1905. On a collection of fishes from the Inland Sea of Japan made by Mr. Gorden Smith. Ann. Mag. Nat. Hist., (7) 15, pp. 17-26, fig. 6.

1908. Report on the marine fishes collected by Mr. J. Stanley GARDINER in the Indian Ocean. Trans. Linn. Soc. London, Zool. Second series, 12 (3), pp. 217-225, pls. 23-32.

RICHARDSON, J. 1846. Report on the ichthyology of the seas of China and Japan. Rep. British Assoc. Adv. Sci. for 1845, pp. 187-320.

Roxas, H. A. and MARTin, C. 1937. A check list of Philippine fishes. Commonwealth of the Philippines Department of Agriculture and Commerce, Manila, Technical Bull. 6, pp. 1-314.

Schmidt, P. 1931 a. A list of fishes, collected in Japan and China by Dr. A. Bunge and N. GREBNJTZKy. Bull. l'Acad. Sci. L'URRS, pp. 101-123, figs, 1-5.

1931 b. Fishes of Japan, collected in 1901. Trans. Pacific Comm. Acad. Sci. USSR,

2 , pp. 1-176, figs. $1-30$.

and LinDBerg, G. 1930. A list of fishes collected in Tsuruga (Japan) by W. RoszkowaKI. Bull. L'Acad. Sci. L'URSS, pp. 1135-1150, fig. 1.

SchulTz, L. P. and WoOds, L. P. 1948. A new name for Synchiropus altivelis, with a key to the genera of the fish family Callionymidae. Jour. Washington Acad. Sci., 38 (12), pp. 419-420.

Seale, A. 1914. Fishes of Hong Kong. Philippine Jour. Sci., 9 (1), pp. 59-81, pls. 1-2.

Smith, J. L. B. 1949. The sea fishes of southern Africa. xvi+550 pp., 105 pls., Central New Agency, Cape Town.

and Pope, T. E. B. 1906. List of fishes collected in Japan in 1903, with descriptions of new genera and new species. Proc. U.S. Nat. Mus., 31 (1489), pp. 459-499, figs. 1-12.

SNYDER, J. O. 1912. Japanese shore fishes collected by the United States Bureau of Fisheries Steamer "Albatross" expedition of 1906. Proc. U.S. Nat. Mus., 42 (1908), pp. 399-450, fig. 1, pis. 51-61.

TANAKA, S. 1917. Eleven new species of fishes from Japan. Zool. Mag, 29 (339), pp. 7-12. [In Japanese.]

1931. On the distribution of fishes in Japanese waters. Jour. Fac. Sci., Imp. Univ. Tokyo, Sec. 4, Zool., $3(1)$, pp. 1-90, pls. 1-3.

'Temminck, C. J. and SChlegel, H. 1842-1847. Stebold's Fauna Japonica, 2 (Pisces), 323 pp., 143 pls., Lupl. pl. A. Leiden.

UI, N. 1929. Monograph of fishes from Prov. Kii. $284+45$ pp., 108 figs., 3 pls. Takahashi Naneki-Sha, Osaka. [In Japanese.]

Wu, H; W. 1931. Notes on the fishes from the coast of Foochow region and Ming River. Cont. Biol. Lab. Sci. Soc. China, 7 (1), pp. 1-64, figs. 1-10.

YANAI, R. 1950. Fishes of San'in District. Zool. Mag., 59 (1), pp. 17-22. [In Japanese.] 